Estuarine, Coastal and Shelf Science

January 2015, Volume 152, Pages 11-22

http://dx.doi.org/10.1016/j.ecss.2014.11.005

http://archimer.ifremer.fr/doc/00226/33747/

(c) 2014 Elsevier Ltd. All rights reserved.

\title{
Community, Trophic Structure and Functioning in two contrasting Laminaria hyperborea forests
}

\author{
Leclerc Jean-Charles ${ }^{1,2,{ }^{*}}$, Riera Pascal ${ }^{1,2}$, Laurans Martial ${ }^{3}$, Leroux Cedric ${ }^{1,4}$, Lévêque Laurent ${ }^{1,4}$, \\ Davoult Dominique ${ }^{1,2}$
}

${ }^{1}$ Sorbonne Universités, UPMC Univ Paris 6, Station Biologique de Roscoff, Place Georges Teissier, 29680 Roscoff, France

${ }^{2}$ CNRS, UMR 7144 AD2M, Station Biologique de Roscoff, Place Georges Teissier, 29680 Roscoff, France

${ }^{3}$ IFREMER, Laboratoire de Biologie Halieutique, Centre Bretagne, BP 70,29280 Plouzané, France

${ }^{4}$ CNRS, FR 2424, Station Biologique de Roscoff, Place Georges Teissier,29680 Roscoff, France

*Corresponding author : Jean-Charles Leclerc, email address : leclercic@gmail.com

\begin{abstract}
:
Worldwide kelp forests have been the focus of several studies concerning ecosystems dysfunction in the past decades. Multifactorial kelp threats have been described and include deforestation due to human impact, cascading effects and climate change. Here, we compared community and trophic structure in two contrasting kelp forests off the coasts of Brittany. One has been harvested five years before sampling and shelters abundant omnivorous predators, almost absent from the other, which has been treated as preserved from kelp harvest. $\delta 15 \mathrm{~N}$ analyses conducted on the overall communities were linked to the tropho-functional structure of different strata featuring these forests (stipe and holdfast of canopy kelp and rock). Our results yielded site-to-site differences of community and tropho-functional structures across kelp strata, particularly contrasting in terms of biomass on the understorey. Similarly, isotope analyses inferred the top trophic position of Marthasterias glacialis and Echinus esculentus which may be considered as strong interactors in the sub-canopy. We interrogate these patterns and propose a series of probable and testable alternative hypotheses to explain them. For instance, we propose that differences of trophic structure and functioning result from confounded effects of contrasting wave dissipation depending on kelp size-density structure and community cascading involving these omnivorous predators. Given the species diversity and complexity of food web highlighted in these habitats, we call for further comprehensive research about the overall strata and tropho-functional groups for conservation management in kelp forests.
\end{abstract}

Keywords: Laminaria hyperborea, Community cascade, Stable isotopes, Biomass, Suspension-feeders, Omnivorous predators

\section{Introduction}

Worldwide kelp forests harbour high biodiversity and host complex biological interactions, expected to promote their stability (see Steneck et al., 2002 and Filbee-Dexter and Scheibling, 2014 for reviews). In North-eastern Atlantic, kelp forests are dominated by 
Laminaria hyperborea, a species distributed from Portugal to Northern Norway, at depths ranging from 0 to $30 \mathrm{~m}$ (Kain, 1971). In pristine areas, Laminaria hyperborea individuals can reach up to $3.5 \mathrm{~m}$ in length and can be considered as a habitat of their own composed of three stratified parts: the lamina, the stipe, and the holdfast. Among these strata, associated communities are particularly diverse and differently distributed (Moore, 1973; Schultze et al., 1990; Christie et al., 2003). Community structure and distribution of mobile fauna has often been linked to the structural complexity of kelp individuals (Jones, 1971; Moore, 1973) and epiphytic seaweeds (Norderhaug et al., 2002; Christie et al., 2007). Within epiphytes and holdfasts, environmental factors such as turbidity and wave exposure, interacting with the complexity of seaweed forming-habitat, can also influence mobile fauna distribution (Moore, 1973; Norderhaug et al., 2012; Norderhaug et al., 2014). While these strata have been investigated, understorey communities are still overlooked. The kelp canopy can provide favourable conditions for the development of functionally diverse seaweeds on the surrounding substratum (Norton et al., 1977), expected to shelter complex communities of sessile and mobile fauna.

Among the multiple threats of kelp (see Steneck et al., 2002 for review), sea urchin overgrazing can lead to alternative stable states of the ecosystem dominated by encrusting coralline algae and urchins, commonly named barrens as a consequence of an extensive habitat loss. In northern Europe, some L. hyperborea populations have been particularly studied in Norway, and overgrazing events were reported owing to the local abundance of the green sea urchin Strongylocentrotus droebachiensis, co-occurring with the edible sea urchin Echinus esculentus (Sivertsen, 1997). While S. droebachiensis feeds either on adult or young kelp, E. esculentus grazing seems mostly restricted to the understorey kelp recruits and other algae, and can exercise some control over L. hyperborea forests and associated communities (Jones and Kain, 1967; Sjøtun et al., 2006; Norderhaug and Christie, 2009). On the rocky shores of Brittany, below the southern distribution of S. droebachiensis, only a few grazers, including E. esculentus, are able to feed directly on kelp. This report has been suggested to favour their local persistence (Leblanc et al., 2011). Interestingly, E. esculentus has also been described as an omnivorous (i.e. feeding on several trophic level) and opportunistic predator (Allen, 1899; Forster, 1959; Comely and Ansell, 1988). Variable foraging behaviour such as omnivory can be of critical importance in strengthening food web interactions, including cascading effects (Emmerson and Yearsley, 2004; Bruno and O'Connor, 2005; O'Gorman and Emmerson, 2010). For instance, it has been proposed, on the base of modelled food webs, that a stable community should be favoured since omnivorous interactions are weak (Emmerson 
and Yearsley, 2004). In complex coastal mesocosm communities, manipulating the abundance of strong interactors, such as predator echinoderms, has been shown to skew food web properties without any impact on species richness (O'Gorman and Emmerson, 2010).

In Brittany, L. hyperborea is harvested for almost two decades, given their quantity of alginic acid, valuable for stabilizing and suspending properties (Chapman and Chapman, 1980). The major part of kelp exploitation is localized within the 'Parc Naturel Marin d'Iroise' which was created in 2007 in order to reconcile the environmental management with the development of human activity, and actually differs from a sanctuary. Within the park, the net kelp trawling ranged officially between 2,000 and 12,300 tons per year during the last decade. With regards to previous studies dealing with kelp dynamics and rate of stipe production with age (Sjøtun et al., 1993; Sjøtun and Fredriksen, 1995), harvesting has been zoned on the basis of a five year-rotation system. Up to now, the lack of knowledge about the recovery of communities and food web associated with kelp forests indicates the need for further long-term researches, taking into account their overall components (Sivertsen, 1997; Christie et al., 1998; Waage-Nielsen et al., 2003; Lorentsen et al., 2010; Smale et al., 2013). An individual L. hyperborea may reach up about 20 years old and produce a new hapteron ring around its holdfast during each spring (Kain, 1963; Rinde and Sjøtun, 2005). From one year to another, this peripheral growth increases both the structural complexity and the size of the holdfast forming microhabitat, hence promoting the colonization and the diversity of associated assemblages (Jones, 1971; Christie et al., 1998). Studies of microhabitat complexity should also be improved considering the surrounding substratum, which is mainly overlooked in European kelp forests despite its value for local diversity (Waage-Nielsen et al., 2003). Given the heterogeneous topography and the local cover by functionally diverse and abundant organisms (Norton et al., 1977), the rock represents a complex biotope important in management.

The present study aimed to report biodiversity and trophic structure patterns associated with two L. hyperborea forests of contrasting conditions and histories. Though comparable overall kelp densities, one area has been moderately kelp-harvested for almost one decade, whereas the other has been, to our knowledge, preserved from exploitation. In parallel, the former has been consistently observed to shelter large echinoderms (sea-urchins and sea-stars) in important densities, nearly absent from the other. We investigated patterns in diversity and biomass distribution of macroalgae and macrofauna species across kelp forest strata, and understory megafauna densities between sites. These patterns are discussed according to biomass distribution of tropho-functional group and trophic level estimations in order to offer 
alternative hypotheses to explain these stratum-dependent patterns and their potential implications in future kelp forest conservation management.

\section{Material \& Methods}

\subsection{Study sites}

The study sites were located near Roscoff and within the Molène archipelago (Fig. 1) along the north-western coast of Brittany. These sites, separated by $70 \mathrm{~km}$, are part of the same well-mixed (throughout the year) water mass at the English Channel entrance (Birrien et al., 1991). The Roscoff site $\left(48^{\circ} 43.556 \mathrm{~N}, 4^{\circ} 01.415 \mathrm{~W}\right)$ is a dense, sheltered boulder field with some coarse interstitial sediment, lying upon a flat rocky reef, situated $1 \mathrm{~km}$ from the shore and $2.5 \mathrm{~m}$ below chart datum. The kelp forest $\left(\approx 1 \mathrm{~km}^{2}\right)$ is surrounded by mosaic habitats, represented by offshore infralittoral coarse sand/gravel flats, other kelp forests at comparable depth, few Zostera spp. beds on the infralittoral fringe, intertidal rocky reefs dominated by Fucales, and intertidal fine sand beaches (Joubin, 1909). Unlike in the Molène area, kelp harvesters started to trawl L. hyperborea in 2007, for an official net crop ranging between 300 and 3,300 tons per year up to now. From diver observations and information provided by local fishermen, the Roscoff study site was considered to be preserved from kelp-harvesting, but was frequently exploited for abalones and large decapods. During autumn 2010, L. hyperborea densities were measured on the site within $0.25 \mathrm{~m}^{2} 3$-sided quadrats $(n=60)$, for three size classes: $0-10 \mathrm{~cm}, 10-40 \mathrm{~cm},>40 \mathrm{~cm}$. Densities were estimated at $16.9 \pm 11.4$ individuals $\mathrm{m}^{-2}$ ( \pm S.D.), largely dominated by adults from the canopy layer (Stipe $>40 \mathrm{~cm}$, $13.1 \pm 6.6$ ind. $\left.\mathrm{m}^{-2}\right)$. The Molène site $\left(48^{\circ} 25.089 \mathrm{~N}, 4^{\circ} 54.742 \mathrm{~W}\right)$ is located within the 'Parc Naturel Marin d'Iroise'. This site is a boulder field with some coarse interstitial sediment, lying upon a flat rocky reef ('Helle' plateau), situated $3.5 \mathrm{~km}$ from the nearest shore (Molène Island) and $9.0 \mathrm{~m}$ below chart datum. The 'Helle' plateau $\left(\approx 8 \mathrm{~km}^{2}\right)$ is surrounded by circalittoral heterogeneous sand flats and infralittoral coarse biogenic gravel and heterogeneous sand beds (Raffin, 2003). According to fishermen (Ifremer data), $L$. hyperborea was not harvested at this site for five years before sampling. During March 2011, after winter recruitments, kelp densities were estimated within $1 \mathrm{~m}^{2}$ quadrats $(n=15)$ at 18.1 \pm 9.1 individuals $\mathrm{m}^{-2}$ ( \pm S.D.), dominated by medium individuals (Stipe $10-40 \mathrm{~cm}, 5.1 \pm 2.5$ ind. $\left.\mathrm{m}^{-2}\right)$ and adults $\left(6.9 \pm 3.2\right.$ ind. $\left.\mathrm{m}^{-2}\right)$. Although kelp density displayed site-to-site differences in the size-canopy structure, any causal link with kelp trawling cannot be established since initial condition and temporal variability within both sites remains unknown (Osenberg and Schmitt, 1996). 


\subsection{Community and trophic structure}

Sampling was performed by scuba-divers in late March 2011 (early spring). At each sampling site, L. hyperborea adults $(n=5)$ were randomly collected in $1 \mathrm{~mm}$ mesh bags (Christie et al., 2003). A substantial part of the within-site variability in the biotic colonisation of kelp can be explained by age and size of kelp (Whittick, 1983; Anderson et al., 2005); therefore only adult kelp from the canopy layer were selected underwater by their total length (1-2 $\mathrm{m})$ before further biometric analyses in the laboratory. Few mobile species inhabit the lamina (Norton et al., 1977; Christie et al., 2003); therefore stipe and its adjoining lamina were collected in the same bag and the holdfast was collected separately. The surrounding substratum was sampled in $0.1 \mathrm{~m}^{2}$ quadrats $(n=5)$ using an air pump connected to a $1 \mathrm{~mm}$ mesh collector.

In the laboratory, each bag was carefully rinsed with seawater over a $500 \mu \mathrm{m}$ mesh sieve. Bag contents were fixed in their entirety with a buffered formaldehyde solution $(3 \%)$. Fauna and flora were sorted according to origin (stipe/lamina, holdfast or rock) and their ashfree dry mass (AFDM) determined at the species level, except for pooled measurement of the Corallinale/Peyssonelia sp. encrusting complex (Kennelly, 1989). In addition to mass measurement of their different parts, adult kelps were processed for age, size and holdfast volume. Individual kelp were aged using the method of Kain (1963), ranging from 3 to 8 years without any difference between sites (Appendix A, t-test, $t=-0.717, P=0.494$ ). While no difference was detected for stipe length $(72-128 \mathrm{~cm})$ and mass $(21.5-67.7 \mathrm{gAFDM})$, the mean diameter (measured from 5 points per stipe) was slightly higher in Molène $(2.8 \pm 0.5$ $\mathrm{cm})$ than in Roscoff $(2.3 \pm 0.2, t=-4.30, P=0.003)$ but difference in the calculated surface area was not significant $(P=0.052)$. Each holdfast was packed in a thin Ziploc bag and pushed in a transparent water jar, allowing to create a vacuum and to measure its total displacement volume. Holdfast interstitial volume (named 'ecospace' in Jones, 1971) was determined by the difference between total and hapteron displacement volumes, measured in a graduated tube once dissected throughout fauna sorting. Neither these volumes nor holdfast biomass differed significantly between sites ( $P>0.05$, Appendix A).

Additional random collection conducted for isotopic analyses (see below) and scubadiving observations $\left(\approx 5^{\prime}\right.$ ) provided wider qualitative information on communities and trophic structure in spring 2011. These observations were strengthened by a quantitative survey set up for winter 2013. It should be noted that Molène area was patchily trawled the next day after the spring 2011 sampling and may have influenced, by modifying the dissimilarity between 
sites, the results of this additional survey. Megafauna (width $>5 \mathrm{~cm}$ ) densities were estimated by three scuba-divers in Roscoff (late January) and in Molène (mid-February). Dominant species (large molluscs, crustaceans, echinoderms) were counted on the evident rock substratum and below 10 medium boulders (with a diameter of $50-100 \mathrm{~cm}$ ) randomly turned over along three parallel $25 \times 2 \mathrm{~m}$ transects (spaced by $3 \mathrm{~m}$ ).

\subsection{Sampling and preparation for stable isotope analyses}

In late March 2011, at Roscoff and Molène sites, three replicates of seawater (5 L) were collected with a Niskin bottle below the surface $(-1 \mathrm{~m})$ to assess the suspended particulate organic matter (POM). Sediment organic matter (SOM) was obtained by scraping the first $\mathrm{cm}$ of interstitial sediment into $200 \mathrm{~mL}$ containers (3 replicates). Small boulders (3 replicates with a volume of approximately $1 \mathrm{~L}$ ) were collected to sample epilithic biofilms (rock organic matter, ROM). Additional kelp holdfasts (3 replicates) were also brought back to the laboratory to extract the associated organic matter (holdfast organic matter, HOM). SOM, ROM and HOM were considered as the components of the organic matter pool (called $\mathrm{OM}$ pool hereafter). The most abundant macroalgae and consumer species were collected (1 mm mesh bags) from three stipe/lamina samples, three holdfasts and from the surrounding substratum. Zooplankton tows $(200 \mu \mathrm{m})$ were conducted for 10 minutes at approximately $1 \mathrm{~m}$ below the water surface for copepod isotope analyses.

In the laboratory, seawater samples (POM) were filtered on pre-combusted Whatman ${ }^{\circledR} \mathrm{GF} / \mathrm{F}$ filters $(0.7 \mu \mathrm{m})$. Sediment samples were shaken in filtered seawater $(0.20 \mu \mathrm{m})$ to suspend the SOM. Sampled rock boulders were gently brushed using a smooth brush in filtered seawater $(0.20 \mu \mathrm{m})$ to suspend ROM. HOM was brushed from within the holdfast base using a similar smooth brush in filtered seawater $(0.20 \mu \mathrm{m})$. Brushing was brief to minimise the release of extracellular polymeric substances (EPS) by the holdfast which could bias the isotope signature of the HOM. Suspended SOM, ROM, and HOM were sieved separately on a $63 \mu \mathrm{m}$ mesh and filtered on $0.7 \mu \mathrm{m}$ GF/F filters. Although stable isotope analyses were focused on $\delta^{15} \mathrm{~N}$ for trophic level estimations in the present paper, some carbonate removal (identical procedures at both sites) was performed for $\delta^{13} \mathrm{C}$ measurements which are presented elsewhere (Leclerc et al., 2013b). Each filter was then briefly acidified (HCL, $1 \mathrm{~N}$ ), thoroughly rinsed with distilled water, and dried at $60{ }^{\circ} \mathrm{C}$ for $48 \mathrm{~h}$.

Macroalgae were sorted by species, washed, and stored in plastic bags at $-30{ }^{\circ} \mathrm{C}$ until preparation and analysis. L. hyperborea samples were separated according to the different thallus parts, namely old lamina (distal part), young lamina (formed during winter), stipe 
(close to the meristem) and EPS. EPS were extracted from stipe pieces cut longitudinally, disposed above large glass containers and maintained for $1 \mathrm{~h}$ at ambient temperature. EPS samples were directly dried at $60{ }^{\circ} \mathrm{C}(48 \mathrm{~h})$ before grinding. Zooplankton samples were placed in a test tube from which light was excluded except for the top tenth of the tube. A cold light source was placed at the top and copepods attracted by the light were sorted from the living material using a pipette and kept in $0.20 \mu \mathrm{m}$ filtered seawater for $3 \mathrm{~h}$ to allow gut clearance. Macro-consumers were starved overnight in $0.20 \mu \mathrm{m}$ filtered seawater to allow evacuation of their digestive contents. Samples were then stored in glass containers at $-30{ }^{\circ} \mathrm{C}$ until preparation and analysis.

Macroalgae pieces were scraped with a scalpel, rinsed with freshwater to remove epiphytes and then briefly acidified (HCL, $1 \mathrm{~N}$ ). Whenever possible, isotope analyses of consumers were conducted on muscle tissue to minimise isotope variability and to reflect integrative assimilation of sources by the consumers (e.g. Pinnegar and Polunin, 1999). Most samples were prepared at the individual level. To obtain sufficient material for accurate stable isotope analyses, a few samples containing several individuals of the same taxa were pooled (Copepoda, Nematoda, Odontosyllis ctenostoma, Rissoa parva, Barleeia unifasciata, Janira maculosa, and colonial taxa: Bryozoa and Ascidiacea). Each sample was then briefly acidified (HCL, $1 \mathrm{~N}$ ), rinsed with distilled water, and dried at $60{ }^{\circ} \mathrm{C}$ for $48 \mathrm{~h}$. In order to cope with changes induced by longer acidifications, $\delta^{15} \mathrm{~N}$ measurements were conducted on untreated samples for calcareous organisms (Corallina, Sycon, Crisa, Didemnum, Marthasterias, Asterias and Amphipholis). Once dried, samples were crushed with a mortar and a pestle then put in tin capsules before mass-spectrometry analyses.

Nitrogen isotope ratios were determined using a Flash EA CN analyser coupled with a Finnigan Delta Plus mass spectrometer, via a Finnigan Con-Flo III interface. Data are expressed in the standard $\delta$ unit.

$$
\delta^{15} \mathrm{~N}=\left[\left({ }^{15} \mathrm{~N} /{ }^{14} \mathrm{~N}_{\text {sample }} /{ }^{15} \mathrm{~N} /{ }^{14} \mathrm{~N}_{\text {reference }}\right)-1\right] \times 10^{3}
$$

These abundances were calculated in relation to the certified reference material atmospheric dinitrogen (at-air). The at-air scale was obtained using in-house protein standards, calibrated against IAEA N3 reference material. The standard deviation of repeated measurements of $\delta^{15} \mathrm{~N}$ values of a laboratory standard was $0.05 \%$ versus at-air.

\subsection{Data analyses}

Community structures were analysed for macroalgae and macrofauna separately, according to habitat (stipe/lamina, holdfast and rock) and site (Roscoff, Molène), using 
PRIMER 6 (Plymouth Routine in Multivariate Ecological Research) software. Previously, species AFDM were standardised by the total biomass per sample (i.e. biomass percentages). Prior analyses, one outlier sample (rock quadrat from Molène), containing one megafauna individual (Marthasterias glacialis, $82 \%$ AFDM of the sample) have been excluded. Similarities among samples were estimated using the Bray-Curtis Similarity Index (Clarke and Warwick, 2001). Samples were ordinated using a non-metric Multidimensional Scaling (nMDS) and differences among sites and habitats (both fixed factors) were analysed using permutational multivariate analyses of variance (PERMANOVA, Anderson et al., 2008), allowing testing whether inter-group similarity is greater than within-group. Species biomass distributions between sites within each habitat were compared using pair-wise tests, depending on significant interactions between the two factors. Within each habitat group, PERMDISP routine revealed that the multivariate dispersion (around the centroid) of biomass distribution of seaweeds and fauna was homogeneous between sites $(P>0.15)$.

For each microhabitat, biomasses of large tropho-functional groups were compared between sites. For that purpose, different biomass standardisations were conducted, according to the microhabitat considered, except for rock samples $\left(0.1 \mathrm{~m}^{-2}\right)$. Biomass of seaweed or consumer groups was standardised either by lamina, stipe or holdfast biomass. In order to characterize habitat features that may influence faunal distribution (Christie et al., 2007; Norderhaug et al., 2014), red, brown and green macroalgae (considered as trophic groups) were separated according to their morphology: crustose, smooth leaf-like (poorly branched), rough leaf-like (coarsely branched), bush-like (densely branched). Consumers were separated according to their major feeding mode: grazer, sessile suspension-feeder (including sessile bivalves), mobile suspension-feeder, deposit-feeder, mobile fauna- and sessile faunapredators. When the homoscedasticity hypothesis was achieved (Fisher tests), the mean biomass of tropho-functional groups was compared between sites using one-tailed Student $t$ tests. Otherwise, a Wilcoxon-Mann-Whitney $U$-test was applied. Megafauna densities in transects $(25 \times 2$ m, 3 replicates, winter 2013) were considered between Roscoff and Molène using one-tailed Wilcoxon-Mann-Witney $U$-test. For biomass and density site-to-site comparisons, tropho-functional groups of consumers and primary producers were all considered as independent entities owing to the lack of a priori knowledge on their interrelationships; therefore multiple site-to-site paired comparisons were chosen. Freeware $\mathrm{R}$ statistical environment was used for all these statistical analyses (R Development Core Team, 2012).

Isotopic analyses helped to estimate consumer trophic levels ( $\left.\mathrm{TL}_{\text {consumer }}\right)$ as follows: 


$$
\mathrm{TL}_{\text {consumer }}=2+\left(\delta^{15} \mathrm{~N}_{\text {consumer }}-\delta^{15} \mathrm{~N}_{\text {baseline }}\right) / 2.5
$$

where $\delta^{15} \mathrm{~N}_{\text {baseline }}$ corresponds to the mean $\delta^{15} \mathrm{~N}$ of strict primary consumers $(\mathrm{TL}=2.0)$. Only the species sampled at both sites were used as baseline in order to strengthen TL site-to-site comparisons, regardless of the trophic enrichment factor (TEF) choice. The latter was chosen according to Caut et al. (2009) who reported a mean $\delta^{15} \mathrm{~N}-\mathrm{TEF}$ value of $2.5 \%$ o for invertebrate whole body. With regard to the large variability of TEF within this group (Caut et al., 2009), the corresponding uncertainty in TL estimation was 0.9 (S.D.). Since $\delta^{15} \mathrm{~N}$ fractionation depends, among other factors, on the protein content of the mixed food source (Perga and Grey, 2010), considering this variability in estimations is essential when considering strong omnivory occurring in food webs. It should be noted that the TL was estimated from species mean $\delta^{15} \mathrm{~N}$; hence the intraspecific variability of TL was not taken into account in results.

\section{Results}

\subsection{Community structure}

Among the 65 macroalgal taxa identified across sites (Table 1, Appendix B), 9 were found on lamina, 34 on stipe, 43 on holdfast, 53 on the surrounding substratum. These taxa were differently distributed among microhabitats, within each site (Fig. 2A, Table 2A). The canopy (lamina and stipe) epiphytic relative composition did not differ between Roscoff and Molène (pair-wise tests), and was characterised on its own. On lamina, the seaweed species richness (Table 1) and tropho-functional group biomass (Fig. 3A) were similar between sites. Brown algae (on average $20 \mathrm{mgAFDM}$ gAFDM $_{\text {Lamina }}{ }^{-1}$ ) were largely dominated by the filamentous Ectocarpus sp. while red algae $\left(\approx 10 \mathrm{mgAFDM} \mathrm{gAFDM} \mathrm{Lamina}^{-1}\right)$ were dominated by the rough leaf like Cryptopleura ramosa. On stipe, biomass of epiphytic seaweeds was dominated (Fig. 3B) by smooth leaf-like (Palmaria palmata and Rhodymenia pseudopalmata) and rough leaf-like red algae (Phycodrys rubens, Cryptopleura ramosa). Although the biomasses of these two dominant groups and biomass distribution of the overall species were similar between sites, Roscoff stipes were represented by twofold higher species richness (Table 1) and higher biomass for crustose and bush-like red algae. On holdfast, the species richness did not differ (Table 1), whereas species relative abundances differed significantly between sites (Pair-wise test, Table 2A), as observed at the tropho-functional group level (Fig. 3C). Highly variable on holdfasts, red algae biomass did not differ significantly between sites, except for the crustose corresponding to Corallinale/Peyssoniella sp., absent in Molène and abundant in Roscoff). On the surrounding substratum (Table 1), obvious differences were highlighted between sites (Fig. 2A, Table 2A). In Molène, the biomass associated with the 
rock substratum was dominated by smooth leaf-like brown algae (Fig. 3D), i.e. Saccorhiza polyschides and Laminaria hyperborea recruits. In Roscoff, red algae, distributed among diverse functional groups, dominated the biomass. Compared to Molène, greater biomasses were found for smooth leaf-like (e.g. Dilsea carnosa and Callophyllis laciniata), rough leaflike (e.g. Delesseria sanguinea, Phyllophora crispa), and bushy red algae (e.g. Corallina elongata and Heterosiphonia plumosa).

Among the 279 macrofauna taxa identified on total across sites and habitats (Appendix C), 145 were found on stipe, 191 on and within holdfast and 204 on the rock. Irrespective of the strata analysed, the species richness of sessile fauna (Bivalvia included) was comparable between Roscoff and Molène (Table 1). Mobile fauna richness was comparable on kelp individuals between site, with numerical abundance of 151 to 407 individuals in Molène, and 92 to 360 in Roscoff. On the rocky substratum, mobile fauna species richness was significantly greater in Roscoff (Table 1) and represented by 145-398 ind. $0.1 \mathrm{~m}^{-2}$ against 4097 ind. $0.1 \mathrm{~m}^{-2}$ in Molène. Each microhabitat was characterised by its own macrofauna species biomass distribution and differed between sites. (Fig. 2B, Table 2B). These species were largely dominated by sessile suspension-feeders which represented on average 53 to 99 $\%$ of the consumer biomass according to microhabitat and site (Fig. 4). On stipe + lamina (Fig. 4A), the biomass of sessile suspension-feeders in Molène (44 mgAFDM gAFDM Stipe $^{-1}$ ) was double that in Roscoff (16), mainly due to species growing on the stipe itself. In Molène, this group was dominated by the ascidian Distomus variolosus (62\%), and the bryozoan Celleporina calciformis (12.8) whereas Roscoff stipes were mostly encrusted by the sponge Ophlitaspongia papilla and the bryozoan Phaeostachys spinifera. Higher grazer biomass was observed in Roscoff ( $4 \mathrm{mgAFDM}_{\mathrm{gAFDM}} \mathrm{Stipe}^{-1}$ ), mostly due to the gastropod Gibbula cineraria (67\%). Within holdfast, the macrofauna biomass (Fig. 4B) was higher in Roscoff, particularly for sessile suspension-feeders and deposit-feeders (e.g. Rissoa parva, Eupolymnia nesidensis). In Roscoff, sessile suspension-feeders were dominated by sponges (Amphilectus fucorum, Myxilla incrustans, Ophlitaspongia papilla, Halisarca dujardini) and didemnid ascidian (Didemnum maculosum). In Molène, this group was dominated by polyclinid ascidians (Aplidium glabrum and Morchelium argus) and the bryozoan Celleporina calciformis. Between sites, the rocky substratum largely contrasted in biomass distribution of either macrofauna species or trophic group (Table 2B, Fig. 4C). The Roscoff rocky substratum yielded substantial biomass of consumers compared to Molène, except for grazers and mobile fauna-predators (Fig. 4C). The biomass of sessile suspension-feeder was eightfold higher in Roscoff $\left(0.7\right.$ gAFDM $\left.0.1 \mathrm{~m}^{-2}\right)$ than in Molène, dominated by sponges as 
Phorbas plumosum, Amphilectus fucorum, Dysidea fragilis, Myxilla incrustans, Halichondria sp., the ascidians Polyclinum aurantium and the bryozoan Microporella ciliata. The biomass of mobile suspension-feeders was six-fold higher in Roscoff $\left(0.01 \mathrm{gAFDM} 0.1 \mathrm{~m}^{-2}\right)$, and was dominated by the echinoderm Antedon bifida, and the sabellid Branchomma bombyx. Depositfeeder biomass was three-fold higher $\left(0.1 \mathrm{mgAFDM} 0.1 \mathrm{~m}^{-2}\right)$ in Roscoff, mostly represented by terebellids such as Pista elongata or Eupolymnia nesidensis, echinoderms as Amphipholis squamata, and many gastropods such as Bittium reticulatum, Barleeia unifasciata, Rissoa parva. The biomass of sessile fauna-predators was treble in Roscoff ( $\left.0.1 \mathrm{mgAFDM} 0.1 \mathrm{~m}^{-2}\right)$ than in Molène, and was dominated by the echinoderm Asterina gibbosa and several gastropods (e.g. Trivia arctica) and annelids (e.g. Haplosyllis spongicola).

Megafauna species were differently distributed between sites (Fig. 5). In Roscoff, the rocky substratum and sub-boulders were dominated by grazing gastropods and predatory decapods, whereas in Molène, these habitats were dominated by echinoderms (mostly predators). The abalone Haliotis tuberculata was found in ten-fold greater density in Roscoff compared to Molène. Among crustaceans, the edible and swimming crabs Cancer pagurus and Necora puber were significantly more abundant in Roscoff, where large echinoderms were almost absent except for Henricia sanguinolenta. Important sea cucumber densities (Cucumaria frondosa and Holothuria forskali) were observed in Molène, significantly higher compared to Roscoff for Holothuria forskali. Predatory echinoderms displayed important densities in Molène, especially for Echinus esculentus $\left(6.7 \pm 3.2\right.$ ind. $\left.50 \mathrm{~m}^{-2}\right)$ and Marthasterias glacialis $(18.3 \pm 8.4)$.

3.2. $\delta^{15} \mathrm{~N}$ of the main sources and consumers

Sources showed important $\delta^{15} \mathrm{~N}$ variations in both sites (Fig. 6). Brown algae $\delta^{15} \mathrm{~N}$ values ranged from 2.1 to $6.1 \%$ in Roscoff and from 1.2 to $8.1 \%$ in Molène, for Laminaria hyperborea young lamina and EPS respectively (Table 3). Red algae $\delta^{15} \mathrm{~N}$ ranged from 3.4 (Phycodrys rubens) to $5.8 \%$ (Rhodymenia pseudopalmata) in Roscoff and from 4.2 (Callophyllis laciniata) to $6.4 \%$ (Delesseria sanguinea) in Molène. The OM pool (POM, SOM, HOM, ROM) $\delta^{15} \mathrm{~N}$ ranged from 4.6 (POM) to $8.9 \%$ (HOM) in Roscoff and from 5.3 (HOM) to $6.7 \%$ o (ROM) in Molène.

As for primary sources, primary consumers displayed large intra-group variability in $\delta^{15} \mathrm{~N}$ (Fig. 6, Table 3). This variability in the baseline (strict primary consumers) induced uncertainty in the trophic level estimation of consumers. Considering fifteen species, the $\delta^{15} \mathrm{~N}$-baseline was $6.9 \pm 1.3(\mathrm{SD})$ in Roscoff and $6.7 \pm 1.2$ in Molène. For grazer group, the 
$\delta^{15} \mathrm{~N}$ values ranged from 6.4 (Gammaropsis maculata) to $9.7 \%$ (Gibbula cineraria) in Roscoff and from 6.5 (Patella pellucida) to $9.0 \%$ (Gibbula cineraria) in Molène. Among suspension-feeders, the $\delta^{15} \mathrm{~N}$ ranged from 4.7 (Musculus subpictus) to $8.2 \%$ (Ophlitaspongia papilla) in Roscoff and from 4.7 (Alcyonidium gelatinosum) to $7.6 \%$ (Ophlitaspongia papilla) in Molène. Among mobile suspension-feeder species, $\delta^{15} \mathrm{~N}$ ranged from 5.9 (Jassa falcata) to $8.2 \%$ (Branchiomma bombyx) in Roscoff and from 6.4 (Branchiomma bombyx) to $7.6 \%$ (Jassa falcata) in Molène. The $\delta^{15} \mathrm{~N}$ of deposit-feeders (including omnivores) ranged from 6.8 (Rissoa parva) to $8.8 \%$ (Maera inaequipes, TL $=2.8$ ) in Roscoff and from 4.7 (Apseudes talpa) to $9.1 \%$ (Leucothoe spinicarpa, $\mathrm{TL}=3.0$ ). Sessile fauna-predator $\delta^{15} \mathrm{~N}$ ranged from 8.8 (Ocinebrina aciculata, $\mathrm{TL}=2.8$ ) to $11.8 \%$ (Calliostoma zizyphinum, $\mathrm{TL}=$ 4.0) in Roscoff and from 8.3 (Odontosyllis ctenostoma, TL $=2.6$ ) to $11.7 \%$ (Echinus esculentus, $\mathrm{TL}=4.0$ ) in Molène. Mobile fauna-predator $\delta^{15} \mathrm{~N}$ ranged from 11.1 (Gnathia dentata, $\mathrm{TL}=3.7$ ) to $14.4 \%$ (Homarus gammarus, $\mathrm{TL}=5.0$ ) in Roscoff and from 10.9 (Harmothoe impar, TL = 2.6) to $11.9 \%$ (Eualus occultus, $\mathrm{TL}=4.1$ ) in Molène.

\section{Discussion}

\subsection{Patterns of community, trophic structure and functioning}

Overall, observed patterns in diversity and species distribution were dependent on the taxonomic/functional group (e.g. seaweed, macrofauna, megafauna), as well as on the stratum considered (lamina, stipe, holdfast of canopy plants and rock). Molène and Roscoff Laminaria hyperborea canopy plants (lamina, stipe) hosted similar macroalgal biomass distribution, represented by 37 species in total. In both sites, algal epiphytes were dominated by filamentous Ectocarpus sp. on lamina, smooth leaf-like Palmaria palmata on uppermost part of stipe, rough leaf-like Phycodrys rubens on the middle part, and smooth leaf-like Rhodymenia pseudopalmata, on the lower level of stipe and on holdfast. Across European kelp forests, Palmaria palmata occurs in shallow waters, its lower distribution being limited by light (Norton, 1968; Norton et al., 1977; Whittick, 1983; Castric-Fey, 1996), therefore its abundance as an epiphyte on the same part of stipe in both sites suggests that the irradiance reaching the canopy layer is somewhat comparable in spite of difference in depth (Whittick, 1983). Compared to their well-studied Norwegian counterparts, Brittany Laminaria hyperborea stipes were almost devoid of boreal bushy algae species such as Rhodomela confervoides and Ptilota gunneri (Christie et al., 2007). In lieu of [check if text missing] (see discussion in Whittick, 1983), in Brittany, the split leaf-like Cryptopleura ramosa was found either on the mid-level of stipe, on lamina or on holdfast. Despite similar macroalgae taxa and 
morphologic group biomass distribution between sites, the macrofauna associated with the canopy significantly differed (see also Appendix C) but was mostly due to differences in sessile taxa growing on stipe itself. The absence of Phaeostachys spinifera on Molène stipes can be attributed to its southern limit of distribution in Roscoff, and may explain the development of competitive species such as Distomus variolosus and Celleporina calciformis. The lower abundance of mobile fauna among abundant macroalgal epiphytes in Molène is more difficult to explain since most species are currently reported in European kelp forests (Jones, 1973; Norton et al., 1977; Schultze et al., 1990; Christie et al., 2003; 2014) and may result from patterns observed on the overall forest. While an important dissimilarity in species composition was found among strata, a substantial connectivity exists horizontally among kelp plants and vertically among strata for several mobile taxa (Norderhaug et al., 2002; Waage-Nielsen et al., 2003). The abundance of mobile fauna in kelp epiphytes may therefore interfere with habitat complexity on the understorey and kelp size-density structure (density of adults hosting abundant epiphytes), factors interacting with wave force dissipation (Eckman et al., 1989; Norderhaug et al., 2014). In Norway, Norderhaug et al. (2014) showed higher richness and abundance of mobile fauna associated to kelp epiphytes in intermediate wave-exposed sites. Although contrasting with our findings, this study was performed among sites displaying equivalent kelp densities in the canopy layer, therefore limiting any generalisation to heterogeneous kelp forests.

At the holdfast level, taxonomic and trophic structures differed between sites. Biomass of deposit- and suspension-feeders was higher in Roscoff, and could result from higher particulate organic matter retention (Jones, 1971; Edwards, 1980) in this more sheltered site. Disregarding local hydrodynamics, such retention can be due to contrasting canopy structures (size-density, Eckman et al., 1989) and structural complexity near the bottom. Despite similar interstitial volumes between sites, holdfast from Roscoff hosted important biomass of structurally diverse red algae. For instance, important encrusting by the Corallinale/Peyssonelia sp. complex forms a hard substratum and enhances habitat size for sessile fauna as sponges (e.g. Amphilectus fucorum, Myxilla incrustans) and ascidians (e.g. Didemnum maculosum), and for other red algae species (dominated by smooth and split leaflike species). The seaweed structural complexity (Gee and Warwick, 1994), in addition to the active selective suspension-feeding of ascidians and sponges (Levinton, 1972; Bell, 2008) may favour holdfast organic matter retention (Moore, 1972; Dixon and Moore, 1997), hence amplifying site-to-site differences. Biomass of mobile fauna such as the dominant deposit feeders, Rissoa parva and Eupolymnia nesidensis, considered as 'Turbidity indifferent 
species' by Moore (1973) can benefit from habitat size/complexity and resource availability. Site-to-site differences in holdfast organic matter retention can also be suggested from isotope composition of HOM, more ${ }^{15} \mathrm{~N}$-enriched in Roscoff than the other sources of the OM pool, suggesting a higher bacterial activity (Thornton and McManus, 1994).

On the rocky substratum, taxonomic and functional composition contrasted between the two sites. The biomass of functionally diverse epilithic red algae was higher in Roscoff compared to Molène. Among the dominant red algae inhabiting Roscoff understorey, the bushy Corallina elongata and the smooth leaf-like Dilsea carnosa are generally restricted to shallow waters (Norton, 1968; Norton et al., 1977) and was not expected to be abundant in Molène. Conversely, the deep species (Norton, 1968) Phyllophora crispa and Calliblepharis ciliata represented $37 \%$ of red algae biomass in Roscoff but were nearly absent in Molène. While epiphytic algal composition may be similar on canopy kelp in areas of contrasting histories (Christie et al., 1998), patterns in epilithic structure remain overlooked. Particularly abundant in Roscoff samples, the perennial species Phyllophora crispa has a rigid and rough leaf-like habit, favourable to host diverse red algae, sessile (sponges, bryozoans, ascidians) and mobile fauna, as already reported (Kostylev et al., 2010). Phyllophora crispa and associated epiphytes form a habitat quite comparable to adult kelp holdfasts in terms of complexity and $\mathrm{OM}$ retention (unpubl. obs.). Between sites, the rock habitat was thus profoundly different between sites in term of algal composition and resulting feature. Nearby the bare bottom in Molène, the large variability of brown algae biomass observed on holdfast and rock (Fig. 3C, D) suggests patchy and opportunistic winter settlement of the annual kelp s.l. Saccorhiza polyschides (Norton, 1978; Engelen et al., 2011) and Laminaria hyperborea recruits (Sjøtun et al., 2006).

\subsection{Hypotheses about processes involved in observed patterns}

While the present sampling framework does not allow a complete interpretation of the observed patterns, a series of probable and testable hypotheses can be formulated as thoughts for future research. Differences in habitat structure on the bottom (holdfast and surrounding substratum) between Molène and Roscoff may result from confounding physical and biotic effects. Kennelly (1989) found that subcanopy scouring by the small kelp Ecklonia radiata (C.Agardh) J.Agardh decreases as the stipe length increases. While Laminaria hyperborea adults have an erect and rigid stipe which reduces contacts between the blades and the bottom, young short-stiped forms are more flexible and could have a wider sweeping area and a more intensive scouring, as reported for kelp of comparable habit, e.g. L. pallida Greville 
(Velimirov and Griffiths, 1979) and Pterygophora californica (Reed and Foster, 1984). Consequently, kelp abrasion of understorey turfs (Irving and Connell, 2006) and sessile fauna (Connell, 2003) may be greater within a kelp forest dominated by young plants. Whether such effect occurs during the kelp growth, especially during the recovery of kelp-harvested areas, may be of interest for future research. As explained above, the epiphytic composition suggested that incident light was comparable on upper stratum. However, contrasting kelp size-density structure and turbidity may affect the light reaching the bottom. While adults dominated the Roscoff kelp forest (November 2010), kelp size classes were more evenly distributed in Molène (March 2011). While the negative shading effect of high kelp density on understorey algae is a well-known phenomenon (e.g. Norton et al., 1977; Reed and Foster, 1984; Wernberg et al., 2005), the effect of evenness in multi-layered kelp forests on these parameters remains, to our knowledge, unexplored. Since kelp are known to interfere with turbulence (e.g. Eckman et al., 1989), it would be worth exploring whether this turbulence vary with evenness in size and flexibility and, in turn with light resource partitioning (Middelboe et al., 2006). Nonetheless, the lower abundance of both sciaphilic and photophilic red algae, combined importance of S. polyschides in Molène on the rock indicates that additional factors are involved in these patterns. The lower red algae and sessile fauna cover on Molène subcanopy may also partially result from a cascading effect, which includes indirect and direct interactions involving large echinoderms. Although megafauna densities were measured two years after macrofauna sampling, these estimations reflected the survey observations and isotopic random collections, highlighting the rarity of large echinoderms at Roscoff and their commonness at Molène site. Often reported as a kelp grazer (Jones and Kain, 1967; Fredriksen, 2003), the edible sea urchin Echinus esculentus has also been described as a browsing opportunistic predator (Allen, 1899; Forster, 1959; Comely and Ansell, 1988). Within the Molène benthic community, E. esculentus exhibited one of the highest $\delta^{15} \mathrm{~N}$ (measured on Aristotle lantern), corresponding to a mean trophic level of 4.0 ( \pm 0.9 considering the variability in TEF for invertebrate whole body, Caut et al., 2009). This estimation is consistent with our observations of digestive contents conducted on individuals that have been sampled for stable isotope analyses. Guts contained some seaweed fragments but were dominated by sessile fauna (bivalves, cirripeds, sponges, bryozoans, and ascidians) and associated poorly mobile organisms (e.g. nematodes, $\mathrm{TL}=3.9$ ), of higher fitness interest compared to macroalgal based diet (e.g. Hughes et al., 2005; Vanderklift et al., 2006). Given the sea urchin densities in Molène, this omnivorous species may be partly responsible of the lower biomass of sessile fauna and seaweed. When E. esculentus has been described as an 
important kelp recruit grazer, its density exceeded 3-4 ind. $\mathrm{m}^{-2}$ (in summer, Jones and Kain, 1967; Sjøtun et al., 2006), substantially higher compared to Molène (0.1-0.2 ind. $\mathrm{m}^{-2}$ in winter). Hence, any density-dependant feeding behaviour of E. esculentus according to food availability should be of interest for future research. In the present study, a greater effect can be expected from the spiny sea-star Marthasterias glacialis $(\mathrm{TL}=3.8)$ which shows greater density (0.3-0.6 ind. $\mathrm{m}^{-2}$ in winter). This voracious species feeds opportunistically either on macroalgae, sessile or mobile macrofauna, and can be considered as a key predator in communities of coastal rocky shores (Frid, 1992; Verling et al., 2003; Bonaviri et al., 2009; Tuya and Duarte, 2012). Furthermore, M. glacialis is one of the main predators of the abalone Haliotis tuberculata (Forster, 1962), poorly represented in Molène. While the spiny sea-star can influence the ormer distribution, other controls should be tested. Haliotis spp. require diverse seaweeds in their diet, including fresh red algae of the understorey (Guest et al., 2008; Leclerc et al., 2013a).

In European kelp forests, the dominant starfish predators are the edible and the swimming crabs: Cancer pagurus and Necora puber (Ramsay et al., 2000). In Roscoff, these species and the lobster Hommarus gammarus were the highest benthic predators according to their estimated trophic levels (4.2-5.0). Both Cancer spp. and Necora spp., more abundant in Roscoff, can forage significantly on large echinoderms and play a key role in their regulation (Freire and Gonzalez-Gurriaran, 1995; Ramsay et al., 2000; Steneck et al., 2004; Fagerli et al., 2014). However, given the absence of E. esculentus and M. glacialis in Roscoff, any contribution to the decapod diets cannot be inferred. Since these predators are not echinoderm specialists, it seems improbable that their densities are sufficient to control, even collapse, large echinoderm populations at Roscoff site (Miller, 1985; Sivertsen, 2006), but information about echinoderm recruitments and predation-rate on young stages (Fagerli et al., 2014) is lacking in the area. Multi-scale spatio-temporal variability of large echinoderms population can be altered, at different life history stages, by several crossed factors including the nature of the substratum (Laur et al., 1986; Hamel and Mercier, 1996; Balch and Scheibling, 2000), the depth (Reid, 1935; Jones and Kain, 1967; Comely and Ansell, 1988; Verling et al., 2003), the food availability (Laur et al., 1986; Tuya and Duarte, 2012), the predation pressure (Steneck et al., 2004; Estes et al., 2011), the temperature and epizootics (Scheibling and Stephenson, 1984). In the English Channel, the stochastic repartition of large echinoderm taxa has intrigued several authors for decades (Allen, 1899; de Beauchamp, 1914; Holme, 1966; Ellis and Rogers, 2000). For example, Marthasterias glacialis from shallow waters seems to 
decrease in abundance from the West to the East, but to our knowledge, this issue remains unexplored.

\subsection{Ecological and management implications}

Omnivorous species can be of critical importance for stability and emergent ecosystem properties which strongly depend on the interaction strength (Emmerson and Yearsley, 2004; Bascompte et al., 2005). In the present study, adult E. esculentus and M. glacialis sampled in Molène were estimated to operate from the fourth trophic level, feeding upon a range of three trophic levels. While the diversity of interaction strengths linking these opportunist species to the associated community remains unclear, our results highlighted direct interactions that were concentrated upon the overall sessile suspension-feeder group. Owing to their large body-size and their energetic requirement (O'Gorman and Emmerson, 2010), these species may thus be considered as collectively strong interactors (sensu Berlow, 1999). Their collective effect may be of critical importance for the associated trophic structure and functioning, through community cascading effects, by reducing the morphological diversity toward the bottom, seemingly affecting habitat structure and organic matter retention. In addition to affecting habitat complexity, sessile suspension-feeders composition and abundance can have dramatic influence on ecosystem properties (Gili and Coma, 1998). In kelp forests, many suspension- and deposit-feeders (e.g. Ophiothrix fragilis and Maera inaequipes for ubiquitous examples) are able to select kelp-derived particles (including propagules) among the organic matter pool (e.g. Beviss-Challinor and Field, 1982), and one can wonder whether this function affect kelp recruitments and survival (Dayton, 1985). While experimental manipulations involving direct grazer provide substantial insights on cascading effects, manipulating particle-consumers faces to the difficulty of quantifying particulate basal resource in marine reproduction (O'Gorman and Emmerson, 2010) and limit understanding of their interactions with other species. In the present study, we found more abundant kelp recruits and reduced biomass of suspension-feeder and red algae simultaneously. If omnivorous predators are involved in the observed patterns, these results provides new insights about the sustainability of kelp primary production in Brittany, often attributed to the local rarity of direct kelp consumers (Arzel, 1998; Leblanc et al., 2011). However, Echinus esculentus and Marthasterias glacialis behave opportunistically, so comprehensive analyses of seasonal and density-dependant variations of their diet are required to state on this indirect interaction. Apart from contrasting structure and functioning nearby the bottom, our results highlighted that kelp canopy individuals are major refuges for the development of diverse and 
abundant sessile organisms, in spite of contrasting size structure and kelp forest histories. Alternatively, these results are strong arguments in favour of further comprehensive analyses of the overall kelp forest strata, including the water column (e.g. Lorentsen et al., 2010) for conservative management and understanding of resilience in structure and functioning in kelp forests.

\section{Acknowledgements}

We would like to thank F Gentil and C Broudin for help with animal identification. We are grateful to the marine operations staff at the Roscoff Biological Station "Service Mer \& Observation SBR", especially Y Fontana, W Thomas, M Camusat \& N Guidal for the sampling set-up. This work benefited from the support of the "Parc Naturel Marin d'Iroise", the Brittany Regional Council and the French Government through the National Research Agency with regards to an investment expenditure programme IDEALG which reference is stated as ANR-10-BTBR-04.

\section{References}

Allen, E.J., 1899. On the fauna and bottom-deposits near the thirty-fathom line from the Eddystone grounds to Start point. Journal of the Marine Biological Association of the United Kingdom 5, 365-542.

Anderson, M.J., Diebel, C.E., Blom, W.M., Landers, T.J., 2005. Consistency and variation in kelp holdfast assemblages: spatial patterns of biodiversity for the major phyla at different taxonomic resolutions. Journal of Experimental Marine Biology and Ecology 320, 35-56.

Anderson, M.J., Gorley, R.N., Clarke, K.R., 2008. PERMANOVA+ for PRIMER: Guide to Software and Statistical Methods. PRIMER-E: Plymouth UK.

Arzel, P., 1998. Les laminaires sur les côtes bretonnes: Evolution de l'exploitation de la flottille de pêche, état actuel et perspectives, Ifremer ed. Ifremer, Plouzané.

Balch, T., Scheibling, R.E., 2000. Temporal and spatial variability in settlement and recruitment of echinoderms in kelp beds and barrens in Nova Scotia. Marine Ecology Progress Series 205, 139-154.

Bascompte, J., Melián, C.J., Sala, E., 2005. Interaction strength combinations and the overfishing of a marine food web. Proceedings of the National Academy of Sciences of the United States of America 102, 5443-5447.

Bell, J.J., 2008. The functional role of marine sponges. Estuarine, Coastal and Shelf Science 79, 341-363.

Berlow, E.L., 1999. Strong effects of weak interactions in ecological communities. Nature 398, 330-334.

Beviss-Challinor, M.H., Field, J.G., 1982. Analysis of a benthic community food web using isotopically labeled potential food. Marine Ecology Progress Series 9, 223-230.

Birrien, J.L., Wafar, M.V.M., Corre, P.L., Riso, R., 1991. Nutrients and primary production in a shallow stratified ecosystem in the Iroise Sea. Journal of Plankton Research 13, 721742 .

Bonaviri, C., Vega Fernández, T., Badalamenti, F., Gianguzza, P., Di Lorenzo, M., Riggio, S., 2009. Fish versus starfish predation in controlling sea urchin populations in Mediterranean rocky shores. Marine Ecology Progress Series 382, 129-138. 
Bruno, J.F., O'Connor, M.I., 2005. Cascading effects of predator diversity and omnivory in a marine food web. Ecology Letters 8, 1048-1056.

Castric-Fey, A., 1996. Richesse et biodiversité en mer mégatidale: communautés sublittorales rocheuses de la région Trebeurden-Ploumanac'h (Nord Bretagne, France). Cahiers de Biologie Marine 37, 7-31.

Caut, S., Angulo, E., Courchamp, F., 2009. Variation in discrimination factors $\left(\Delta^{15} \mathrm{~N}\right.$ and $\left.\Delta^{13} \mathrm{C}\right)$ : the effects of diet isotopic values and applications for diet reconstruction. Journal of Applied Ecology 46, 443-453.

Chapman, V.J., Chapman, D.J., 1980. Seaweeds and their uses. Chapman and Hall.

Christie, H., Fredriksen, S., Rinde, E., 1998. Regrowth of kelp and colonization of epiphyte and fauna community after kelp trawling at the coast of Norway. Hydrobiologia 375$376,49-58$.

Christie, H., Jørgensen, N.M., Norderhaug, K.M., 2007. Bushy or smooth, high or low; importance of habitat architecture and vertical position for distribution of fauna on kelp. Journal of Sea Research 58, 198-208.

Christie, H., Jørgensen, N.M., Norderhaug, K.M., Waage-Nielsen, E., 2003. Species distribution and habitat exploitation of fauna associated with kelp (Laminaria hyperborea) along the Norwegian coast. Journal of the Marine Biological Association of the United Kingdom 83, 687-699.

Clarke, K.R., Warwick, R.M., 2001. Change in marine communities: an approach to statistical and interpretation, 2nd Edition. PRIMER-E: Plymouth, UK.

Comely, C.A., Ansell, A.D., 1988. Population density and growth of Echinus esculentus L. on the Scottish west coast. Estuarine, Coastal and Shelf Science 27, 311-334.

Connell, S.D., 2003. Negative effects overpower the positive of kelp to exclude invertebrates from the understorey community. Oecologia 137, 97-103.

Dayton, P.K., 1985. Ecology of kelp communities. Annual Review of Ecology and Systematics 16, 215-245.

de Beauchamp, P., 1914. Les grèves de Roscoff: étude sur la répartition des êtres dans la zone des marées.

Dixon, I.M.T., Moore, P.G., 1997. A comparative study on the tubes and feeding behaviour of eight species of corophioid Amphipoda and their bearing on phylogenetic relationships within the Corophioidea. Philosophical Transactions of the Royal Society B: Biological Sciences 352, 93-112.

Eckman, J.E., Duggins, D.O., Sewell, A.T., 1989. Ecology of understory kelp environments. I. Effects of kelps on flow and particles transport near the bottom. Journal of Experimental Marine Biology and Ecology 129, 173-187.

Edwards, A., 1980. Ecological studies of the kelp Laminaria hyperborea, and its associated fauna in South-west Ireland. Ophelia 19, 47-60.

Ellis, J.R., Rogers, S.I., 2000. The distribution, relative abundance and diversity of echinoderms in the eastern English Channel, Bristol Channel, and Irish Sea. Journal of the Marine Biological Association of the United Kingdom 80, 127-138.

Emmerson, M., Yearsley, J.M., 2004. Weak interactions, omnivory and emergent food-web properties. Proceedings of the Royal Society of London. Series B: Biological Sciences 271, 397-405.

Engelen, A.H., Lévêque, L., Destombe, C., Valero, M., 2011. Spatial and temporal patterns of recovery of low intertidal Laminaria digitata after experimental spring and autumn removal. Cahiers de Biologie Marine 52.

Estes, J.A., Terborgh, J., Brashares, J.S., Power, M.E., Berger, J., Bond, W.J., Carpenter, S.R., Essington, T.E., Holt, R.D., Jackson, J.B.C., Marquis, R.J., Oksanen, L., Oksanen, T., Paine, R.T., Pikitch, E.K., Ripple, W.J., Sandin, S.A., Scheffer, M., 
Schoener, T.W., Shurin, J.B., Sinclair, A.R.E., Soulé, M.E., Virtanen, R., Wardle, D.A., 2011. Trophic downgrading of Planet Earth. Science 333, 301-306.

Fagerli, C.W., Norderhaug, K.M., Christie, H., Pedersen, M.F., Fredriksen, S., 2014. Predators of the destructive sea urchin Strongylocentrotus droebachiensis on the Norwegian coast. Marine Ecology Progress Series 502, 207-218.

Filbee-Dexter, K., Scheibling, R.E., 2014. Sea urchin barrens as alternative stable states of collapsed kelp ecosystems. Marine Ecology Progress Series 495, 1-25.

Forster, G.R., 1959. The ecology of Echinus esculentus L. Quantitative distribution and rate of feeding. Journal of the Marine Biological Association of the United Kingdom 38, 361-367.

Forster, G.R., 1962. Observations on the ormer population of Guernsey. Journal of the Marine Biological Association of the United Kingdom 42, 493-498.

Fredriksen, S., 2003. Food web studies in a Norwegian kelp forest based on stable isotope $\left(\delta^{13} \mathrm{C}\right.$ and $\left.\delta^{15} \mathrm{~N}\right)$ analysis. Marine Ecology Progress Series 260, 71-81.

Freire, J., Gonzalez-Gurriaran, 1995. Feeding ecology of the velvet swimming crab Necora puber in mussel raft areas of the Ria de Arousa (Galicia, NW Spain). Marine Ecology Progress Series 119, 139-154.

Frid, C.L.J., 1992. Foraging behaviour of the spiny starfish Marthasterias glacialis in lough Ine, Co. Cork. Marine Behaviour and Physiology 19, 227-239.

Gee, J.M., Warwick, R.M., 1994. Body-size distribution in a marine metazoan community and the fractal dimensions of macroalgae. Journal of Experimental Marine Biology and Ecology 178, 247-259.

Gili, J.-M., Coma, R., 1998. Benthic suspension feeders: their paramount role in littoral marine food webs. Trends in Ecology \& Evolution 13, 316-321.

Guest, M.A., Nichols, P.D., Frusher, S.D., Hirst, A.J., 2008. Evidence of abalone (Haliotis rubra) diet from combined fatty acid and isotope analysis. Marine Biology 153, 579588.

Hamel, J.-F., Mercier, A., 1996. Early development, settlement, growth, and spatial distribution of the sea cucumber Cucumaria frondosa (Echinodermata: Holothuroidea). Canadian Journal of Fisheries and Aquatic Sciences 53, 253-271.

Holme, N.A., 1966. The bottom fauna of the English Channel. Part II. Journal of the Marine Biological Association of the United Kingdom 46, 401-493.

Hughes, A.D., Catarino, A.I., Kelly, M.S., Barnes, D.K.A., Black, K.D., 2005. Gonad fatty acids and trophic interactions on the echinoid Psammechinus miliaris. Marine Ecology Progress Series 305, 101-111.

Irving, A.D., Connell, S.D., 2006. Physical disturbance by kelp abrades erect algae from the understorey. Marine Ecology Progress Series 324, 127-137.

Jones, D.J., 1971. Ecological studies on macroinvertebrates associated with polluted kelp forests in the North Sea. Helgolander Wissenschaftliche Meeresuntersuchungen 22, 417-441.

Jones, D.J., 1973. Variation in the trophic structure and species composition of some invertebrate communities in polluted kelp forest in the North Sea. Marine Biology 20, 351-365.

Jones, N.S., Kain, J.M., 1967. Subtidal algal colonization following the removal of Echinus. Helgoland Marine Research 15, 460-466.

Joubin, L., 1909. Recherche sur la distribution océanographique des végétaux marins dans la région de Roscoff., Annales de l'Institut océanlogique de Monaco.

Kain, J.M., 1963. Aspects of the Biology of Laminaria hyperborea II. Age, weight and length. Journal of the Marine Biological Association of the United Kingdom 43, 129151. 
Kain, J.M., 1971. The Biology of Laminaria hyperborea VI. Some Norvegian populations. Journal of the Marine Biological Association of the United Kingdom 51, 387-408.

Kennelly, S.J., 1989. Effects of kelp canopy on understory species due to shade and scour. Marine Ecology Progress Series 50, 215-224.

Kostylev, E.F., Tkachenko, F.P., Tretiak, I.P., 2010. Establishment of "Zernov's Phyllophora field" marine reserve: Protection and restoration of a unique ecosystem. Ocean \& Coastal Management 53, 203-208.

Laur, D.R., Ebeling, A.W., Reed, D.C., 1986. Experimental evaluations of substrate types as barriers to sea urchin (Strongylocentrotus spp.) movement. Marine Biology 93, 209215.

Leblanc, C., Schaal, G., Cosse, A., Destombe, C., Valero, M., Riera, P., Potin, P., 2011. Trophic and biotic interactions in Laminaria digitata beds: which factors could influence the perstistance of marine kelp forests in northern Brittany? Cahiers de Biologie Marine 52, 415-427.

Leclerc, J.-C., Riera, P., Leroux, C., Lévêque, L., Davoult, D., 2013a. Temporal variation in organic matter supply in kelp forests: linking structure to trophic functioning. Marine Ecology Progress Series 494, 87-105.

Leclerc, J.-C., Riera, P., Leroux, C., Lévêque, L., Laurans, M., Schaal, G., Davoult, D., 2013b. Trophic significance of kelps in kelp communities in Brittany (France) inferred from isotopic comparisons. Marine Biology 160, 3249-3258.

Levinton, J., 1972. Stability and trophic structure in deposit-feeding and suspension-feeding communities. The American Naturalist 106, 472-486.

Lorentsen, S.H., Sjøtun, K., Grémillet, D., 2010. Multi-trophic consequences of kelp harvest. Biological conservation 143, 2054-2062.

Middelboe, A., Sand-Jensen, K., Binzer, T., 2006. Highly predictable photosynthetic production in natural macroalgal communities from incoming and absorbed light. Oecologia 150, 464-476.

Miller, R.J., 1985. Seaweeds, sea urchins, and lobsters: a reappraisal. Canadian Journal of Fisheries and Aquatic Sciences 42, 2061-2072.

Moore, P.G., 1972. Particulate matter in the sublittoral zone of an exposed coast and its ecological significance with special reference to the fauna inhabiting kelp holdfasts. Journal of Experimental Marine Biology and Ecology 10, 59-80.

Moore, P.G., 1973. The Kelp fauna of Northeast Britain. II. Multivariate classification: Turbidity as an ecological factor. Journal of Experimental Marine Biology and Ecology 13, 127-163.

Norderhaug, K.M., Christie, H., Andersen, G.S., Bekkby, T., 2012. Does the diversity of kelp forest macrofauna increase with wave exposure? Journal of Sea Research 69, 36-42.

Norderhaug, K.M., Christie, H., Rinde, E., 2002. Colonisation of kelp imitations by epiphyte and holdfast fauna; a study of mobility patterns. Marine Biology 141, 965-973.

Norderhaug, K.M., Christie, H., Rinde, E., Gundersen, H., Bekkby, T., 2014. Importance of wave and current exposure to fauna communities in Laminaria hyperborea kelp forests. Marine Ecology Progress Series 502, 295-301.

Norderhaug, K.M., Christie, H.C., 2009. Sea urchin grazing and kelp re-vegetation in the NE Atlantic. Marine Biology Research 5, 515-528.

Norton, T.A., 1968. Underwater observations on the vertical distribution of algae at St Mary's, Isles of Scilly. British Phycological Bulletin 3, 585-588.

Norton, T.A., 1978. The factors influencing the distribution of Saccorhiza Polyschides in the region of Lough Ine. Journal of the Marine Biological Association of the United Kingdom 58, 527-536. 
Norton, T.A., Hiscock, K., Kitching, J.A., 1977. The ecology of Lough Ine: XX. The Laminaria forest at Carrigathorna. Journal of Ecology 65, 919-941.

O'Gorman, E.J., Emmerson, M.C., 2010. Manipulating interaction strengths and the consequences for trivariate patterns in a marine food web. Advances in Ecological Research 42, 301-419.

Osenberg, C.W., Schmitt, R.J., 1996. Chapter 1 - Detecting Ecological Impacts Caused by Human Activities, in: Schmitt, R.J., Osenberg, C.W. (Eds.), Detecting Ecological Impacts. Academic Press, San Diego, pp. 3-16.

Perga, M.-E., Grey, J., 2010. Laboratory measures of isotope discrimination factors: comments on Caut, Angulo \& Courchamp (2008, 2009). Journal of Applied Ecology 47, 942-947.

Pinnegar, J.K., Polunin, N.V.C., 1999. Differential fractionation of $\delta^{13} \mathrm{C}$ and $\delta^{15} \mathrm{~N}$ among fish tissues: implications for the study of trophic structure. Functional Ecology 13, 225231.

R Development Core Team, 2012. R: A language and environment for statistical computing, R Foundation for Statistical Computing, Vienna, Austria.

Raffin, C., 2003. Bases biologiques et écologiques de la conservation du milieu marin en mer d'Iroise. Université de Bretagne Occidentale, Brest, p. 572.

Ramsay, K., Turner, J.R., Vize, S.J., Richardson, C.A., 2000. A link between predator density and arm loss in the starfish Marthasterias glacialis and Asterias rubens. Journal of the Marine Biological Association of the United Kingdom 80, 565-566.

Reed, D.C., Foster, M.S., 1984. The effects of canopy shading on algal recruitment and growth in a giant kelp forest. Ecology 65, 937-948.

Reid, D.M., 1935. The Range of the Sea-Urchin Echinus esculentus. Journal of Animal Ecology 4, 7-16.

Rinde, E., Sjøtun, K., 2005. Demographic variation in the kelp Laminaria hyperborea along a latitudinal gradient. Marine Biology 146, 1051-1062.

Scheibling, R.1., Stephenson, R., 1984. Mass mortality of Strongylocentrotus droebachiensis (Echinodermata: Echinoidea) off Nova Scotia, Canada. Marine Biology 78, 153-164.

Schultze, K., Janke, K., Krüss, A., Weidemann, W., 1990. The macrofauna and macroflora associated with Laminaria digitata and L. hyperborea at the island of Helgoland (German Bight, North Sea). Helgolander Wissenschaftliche Meeresuntersuchungen 44, 39-51.

Sivertsen, K., 1997. Geographic and environmental factors affecting the distribution of kelp beds and barren grounds and changes in biota associated with kelp reduction at sites along the Norwegian coast. Canadian Journal of Fisheries and Aquatic Sciences 54, 2872-2887.

Sivertsen, K., 2006. Overgrazing of kelp beds along the coast of Norway. Journal of Applied Phycology 18, 599-610.

Sjøtun, K., Christie, H., Fosså, J.H., 2006. The combined effect of canopy shading and sea urchin grazing on recruitment in kelp forest (Laminaria hyperborea). Marine Biology Research 2, 24-32.

Sjøtun, K., Fredriksen, S., 1995. Growth allocation in Laminaria hyperborea (Laminariales, Phaeophyceae) in relation to age and wave exposure. Marine Ecology Progress Series 126, 213-222.1995.

Sjøtun, K., Fredriksen, S., Lein, T.E., Rueness, J., Sivertsen, K., 1993. Population studies of Laminaria hyperborea from its northern range of distribution in Norway. Hydrobiologia 260/261, 215-221. 
Smale, D.A., Burrows, M.T., Moore, P., O'Connor, N., Hawkins, S.J., 2013. Threats and knowledge gaps for ecosystem services provided by kelp forests: a northeast Atlantic perspective. Ecology and Evolution 3, 4016-4038.

Steneck, R., Vavrinec, J., Leland, A.V., 2004. Accelerating trophic-level dysfunction in kelp forest ecosystems of the western north Atlantic. Ecosystems 7, 323-332.

Steneck, R.S., Graham, M.H., Bourque, B.J., Corbett, D., Erlandson, J.M., Estes, J.A., Tegner, M.J., 2002. Kelp forest ecosystems: biodiversity, stability, resilience and future. Environmental Conservation 29, 436-459.

Thornton, S.F., McManus, J., 1994. Application of organic carbon and nitrogen stable isotope and $\mathrm{C} / \mathrm{N}$ ratios as source indicators of organic matter provenance in estuarine systems: Evidence from the Tay Estuary, Scotland. Estuarine, Coastal and Shelf Science 39, 219-233.

Tuya, F., Duarte, P., 2012. Role of food availability in the bathymetric distribution of the starfish Marthasterias glacialis (Lamk.) on reefs of northern Portugal. Scientia Marina 76, 9-15.

Vanderklift, M.A., Kendrick, G.A., Smit, A.J., 2006. Differences in trophic position among sympatric sea urchin species. Estuarine, Coastal and Shelf Science 66, 291-297.

Velimirov, B., Griffiths, C., 1979. Wave-induced kelp movement and its importance for community structure. Botanica marina 22, 169-172.

Verling, E., Crook, A.C., Barnes, D.K.A., Harrison, S.S.C., 2003. Structural dynamics of a sea-star (Marthasterias glacialis) population. Journal of the Marine Biological Association of the United Kingdom 83, 583-592.

Waage-Nielsen, E., Christie, H., Rinde, E., 2003. Short-term dispersal of kelp fauna to cleared (kelp-harvested) areas. Hydrobiologia 503, 77-91.

Wernberg, T., Kendrick, G., Toohey, B., 2005. Modification of the physical environment by an Ecklonia radiata (Laminariales) canopy and implications for associated foliose algae. Aquatic Ecology 39, 419-430.

Whittick, A., 1983. Spatial and temporal distributions of dominant epiphytes on the stipes of Laminaria hyperborea (Gunn.) Fosl. (Phaeophyta: Laminariales) in S.E. Scotland. Journal of Experimental Marine Biology and Ecology 73, 1-10. 
Fig. 1 Location of the two study sites in the Molène archipelago and Roscoff, Brittany (France). Intertidal areas are in clear grey.

Fig. 2 Non-metric Multidimensional Scaling conducted from the Bray Curtis similarities among relative ash free dry mass (standardized by sample total) of macroalgae (A) and macrofauna (B) species in Roscoff (full symbols) and in Molène (empty symbols).

Fig. 3 Macroalgae biomass (AFDM $\pm \mathrm{SD}$ ) according to microhabitats (A: lamina, B: stipe, C: holdfast, D: rock) and sites (Roscoff: full bars, Molène: empty bars) in early spring 2011. Significance of mean difference is indicated: *** $(P<0.001), * *(P<0.01) * *(P<0.05)$, NS $(P>0.05)$, as determined Student or Mann-Whitney tests, according to the homoscedasticity of the data. GA: green algae, BA: brown algae, RA: red algae, Cr: crustose, SmL : smooth leaf-like, RoL: Rough leaf-like, Bu: bush-like.

Fig. 4 Trophic group biomass (AFDM $\pm \mathrm{SD}$ ) according to microhabitats (A: stipe + lamina, B: holdfast, C: rock) and sites (Roscoff: full bars, Molène: empty bars) in early spring 2011. Significance of mean difference is indicated: *** $(P<0.001), * *(P<0.01), *(P<0.05)$, NS $(P>0.05)$, as determined Student or Mann-Whitney tests, according to the homoscedasticity of the data. G: grazers, SSF: sessile suspension-feeders, MSF: mobile suspension-feeders, DF: deposit-feeders, sf-P: sessile fauna-predators, mf-P: mobile fauna-predators.

Fig. 5 Megafauna densities ( $\pm \mathrm{SD})$ per transects $\left(50 \mathrm{~m}^{2}\right)$ measured on the rocky substratum and above 10 boulders in winter 2013 at Roscoff (full bars) and at Molène (empty bars) sites. Significance of mean difference is indicated: *** $(P<0.001), * *(P<0.01), *(P<0.05)$, NS $(P>0.05)$, as determined Student or Mann-Whitney tests, according to the homoscedasticity of the data. Trophic groups (G: grazers, MSF: mobile suspension-feeders, DF: depositfeeders, sf-P: sessile fauna-predators, mf-P: mobile fauna-predators) and Phyla (Moll: Mollusca, Crus: Crustacea, Echi: Echinodermata) are indicated above. Hal: Haliotis tuberculata, Hen: Henrica sanguinolenta, Cuc: Cucumaria frondosa, Hol: Holothuria forskali, Mar: Marthasterias glacialis, Ech: Echinus esculentus, Ast: Asterias rubens, Lui: Luidia ciliaris, Can: Cancer pagurus, Maj: Maja squinado, Nec: Necora puber, Lop: Lophozozymus incisus, Gal: Galathea spp.

Fig. 6 Individual $\delta^{15} \mathrm{~N}(\% \circ)$ values of the main sources of organic matter and consumers according to their dominant trophic group (brown algae (BA), red algae (RA), deposited POM (DPOM), suspended POM (SPOM), grazers $(\mathrm{G})$, sessile suspension-feeders (SSF), mobile suspension-feeders (MSF), deposit-feeders (DF), sessile fauna-predators (sf-P), mobile faunapredator (mf-P) within Roscoff (full dots) and Molène (empty dots) Laminaria hyperborea forests in early spring 2011. 
Table 1 Species richness (Mean \pm S.D. [total]) of macroalgae, mobile fauna and sessile fauna, according to habitat and site. Mean richness were considered between seasons by two-tailed Student $t$-test depending on homoscedasticity of the data. Otherwise a Mann-Whitney $U$-test (marked ${ }^{\text {M.W. }}$ ) was applied. Significant $P$-values are in bold.

Table 2 Results of PERMANOVA and pair-wise tests conducted from the Bray Curtis similarities of macroalgal (A, 65 species) and macrofauna (B, 279 species) species ash free dry mass (standardized by sample total). Site (Roscoff, Molène), Habitat (Lamina, Stipe, Holdfast, Rock), and their interaction were tested. Significant $P$ (perm) are in bold.

Table $3 \delta^{15} \mathrm{~N}(\%, \pm \mathrm{SD})$ of the main primary sources and consumers of the Laminaria hyperborea forests in Roscoff and in Molène, according to their microhabitat (Hab) : stipe $(\mathrm{S})$, holdfast $(\mathrm{H})$, rock $(\mathrm{R})$. Trophic groups (TG) are indicated for consumers: grazers $(\mathrm{G})$, sessile suspension-feeders (SSF), mobile suspension-feeders (MSF), deposit-feeders (DF), sessile fauna-predators (sf-P), mobile fauna-predator (mf-P). Consumer trophic levels (TL \pm $0.9 \mathrm{SD}_{\mathrm{TEF}}$ ) were estimated according to the mean species $\delta^{15} \mathrm{~N}$, or set at the lowest threshold 2.0 .

\section{Electronic Supplementary Materials}

Appendix A Morphometric parameters measured on kelp canopy individuals collected in Roscoff and in Molène. Parameters are compared between sites by Student $t$-tests according to the achievement of homoscedasticity hypothesis.

Appendix B Macroalgal species found at Roscoff and Molène sites during the survey (samples and observations). Relative occurrence is indicated: $x: 1-10 \%$ in samples, $x x: 20-40$ $\%, \mathrm{xxx} 40-100 \%$ according to diversity sampling; ${ }^{\circ}$ : species found in 1 transect, ${ }^{\circ}$ : in 2 transects, ${ }^{\circ \circ}$ : in 3 transects during the megafauna survey.

Appendix C Animal species found at Roscoff and Molène sites during the survey (samples and observations). Relative occurrence is indicated: $\mathrm{x}$ : $1-10 \%$ in samples, $\mathrm{xx}: 20-40 \%$, xxx $40-100 \%$ for diversity samples; ${ }^{\circ}$ : species found in 1 transect, ${ }^{\circ}$ : in 2 transects, ${ }^{\circ \circ}$ : in 3 transects during the megafauna survey. 


\begin{tabular}{|c|c|c|c|}
\hline & ROSCOFF & MOLENE & $\begin{array}{c}\text { Two-tailed } \\
\text { comparison }(P \text {-value })\end{array}$ \\
\hline
\end{tabular}

MACROALGAE $($ Total $=65)$

$\begin{array}{rrrrrrrrrr}\text { Lamina } & 4.6 & \pm & 1.5 & {[9]} & 3 & \pm & 0.8 & {[6]} & 0.104 \\ \text { Stipe } & 17.0 & \pm & 3.6 & {[31]} & 8.8 & \pm & 2.2 & {[14]} & \mathbf{0 . 0 0 4} \\ \text { Holdfast } & 14.4 & \pm & 3.4 & {[33]} & 11.6 & \pm & 3.6 & {[26]} & 0.253 \\ \text { Rock } & 25.8 & \pm & 2.5 & {[42]} & 20.8 & \pm & 7.7 & {[37]} & 0.050\end{array}$

SESSILE FAUNA (Total = 99)

$\begin{array}{rrrrrrrrrr}\text { Stipe } & 25.8 & \pm & 4.4 & {[41]} & 22.2 & \pm & 5.4 & {[39]} & 0.281 \\ \text { Holdfast } & 22.2 & \pm & 5.4 & {[54]} & 31.2 & \pm & 8.6 & {[52]} & 0.841^{\text {M.w. }} \\ \text { Rock } & 28.8 & \pm & 5.4 & {[57]} & 26 & \pm & 5 & {[55]} & 0.389\end{array}$

MOBILE FAUNA $($ Total $=180)$

$\begin{array}{rrrrrrrrrr}\text { Stipe } & 26.8 & \pm & 3.9 & {[55]} & 28.6 & \pm & 9.4 & {[65]} & 0.701 \\ \text { Holdfast } & 31.8 & \pm & 12.2 & {[77]} & 42 & \pm & 11.8 & {[93]} & 0.215 \\ \text { Rock } & 40.0 & \pm & 7.8 & {[94]} & 25.5 & \pm & 4.4 & {[72]} & \mathbf{0 . 0 0 7}\end{array}$

Density

MOBILE FAUNA $($ Total = 4531)

\begin{tabular}{rrrrrrrc} 
Kelp individual & 184.2 & \pm & 109.3 & 244.6 & \pm & 102.9 & 0.394 \\
Stipe & 81.2 & \pm & 32.5 & 82.4 & \pm & 32.2 & 0.955 \\
Holdfast & 103.0 & \pm & 80.8 & 162.2 & \pm & 77.1 & 0.050 \\
Rock & 243.2 & \pm & 58.6 & 76.0 & \pm & 27.3 & $<\mathbf{0 . 0 0 1}$ \\
\hline
\end{tabular}


A. Macroalgae Structure

Source d.f. Pseudo-F $P$ (perm)

\begin{tabular}{lrrr}
\hline Site & 1 & 2.0577 & $\mathbf{0 . 0 2 8}$ \\
Habitat & 3 & 10.68 & $<\mathbf{0 . 0 0 1}$ \\
Site $\times$ Habitat & 3 & 1.835 & $\mathbf{0 . 0 0 4}$ \\
Residual & 32 & & \\
Total & 39 & & \\
\hline Pairwise & & & \\
\hline
\end{tabular}

Pairwise tests between Sites

within levels of Factor "Habitat"

\begin{tabular}{lcr}
\hline \multicolumn{1}{c}{ Levels } & $t$ & $P$ (perm) \\
Lamina & 0.4479 & 0.751 \\
Stipe & 1.3542 & 0.199 \\
Holdfast & 1.2778 & $\mathbf{0 . 0 4 9}$ \\
Rock & 1.6934 & $\mathbf{0 . 0 1 6}$ \\
\hline
\end{tabular}

B. Macrofauna Structure

\begin{tabular}{|c|c|c|c|}
\hline Source & d.f. & Pseudo-F & $P$ (perm) \\
\hline Site & 1 & 9.1935 & $<0.001$ \\
\hline Habitat & 2 & 10.219 & $<0.001$ \\
\hline Site $\times$ Habitat & 2 & 3.673 & $<0.001$ \\
\hline Residual & 23 & & \\
\hline Total & 28 & & \\
\hline
\end{tabular}

Pairwise tests between Sites

within levels of Factor "Habitat"

\begin{tabular}{lrr}
\hline \multicolumn{1}{c}{ Levels } & \multicolumn{1}{c}{$P$ (perm) } \\
Stipe & 2.6752 & $\mathbf{0 . 0 0 8}$ \\
Holdfast & 2.1784 & $\mathbf{0 . 0 0 7}$ \\
Rock & 2.1859 & $\mathbf{0 . 0 1}$ \\
\hline
\end{tabular}




\begin{tabular}{|c|c|c|c|c|c|c|c|c|c|c|c|}
\hline & \multirow[b]{2}{*}{ Hab. } & \multicolumn{5}{|c|}{ Roscoff } & \multicolumn{5}{|c|}{ Molène } \\
\hline TG & & \multicolumn{3}{|c|}{$\delta^{15} \mathbf{N} \pm \mathrm{SD}$} & \multirow[t]{2}{*}{ TL } & \multirow[t]{2}{*}{$n$} & \multicolumn{3}{|c|}{$\delta^{15} \mathbf{N} \pm \mathrm{SD}$} & \multirow[t]{2}{*}{ TL } & $n$ \\
\hline \multirow{2}{*}{\multicolumn{12}{|c|}{ Rhodophyceae }} \\
\hline & & & & & & & & & & & \\
\hline Callophyllis laciniata & $\mathrm{R}$ & 5.4 & \pm & 0.4 & & 3 & 4.2 & \pm & 0.1 & & 3 \\
\hline Corallina elongata & $\mathrm{R}$ & 3.8 & \pm & 0.6 & & 3 & & & & & \\
\hline Delesseria sanguinea & $\mathrm{R}$ & 5.3 & \pm & 0.3 & & 3 & 6.4 & \pm & 0.3 & & 3 \\
\hline Dilsea carnosa & $\mathrm{R}$ & 5.3 & \pm & 0.3 & & 3 & & & & & \\
\hline Heterosiphonia plumosa & $\mathrm{R}$ & & & & & & 6.1 & \pm & 0.3 & & \\
\hline Palmaria palmata & $\mathrm{S}$ & 3.9 & \pm & 0.8 & & 5 & 4.6 & \pm & 0.2 & & 5 \\
\hline Phycodrys rubens & $\mathrm{S}$ & 3.4 & \pm & 0.4 & & 5 & 4.4 & \pm & 0.3 & & 5 \\
\hline Plocamium cartilagineum & $\mathrm{R}$ & 5.2 & \pm & 0.9 & & 3 & & & & & \\
\hline Rhodymenia pseudopalmata & $\mathrm{S}$ & 5.8 & \pm & 0.4 & & 3 & 5.7 & \pm & 0.5 & & 3 \\
\hline \multicolumn{12}{|l|}{ Phaeophyceae } \\
\hline Cystoseira sp. & $\mathrm{R}$ & 3 & \pm & 1.5 & & 3 & & & & & \\
\hline Ectocarpus sp. & $\mathrm{S}$ & 3.1 & \pm & 0.1 & & 3 & 3.6 & \pm & 0.4 & & 3 \\
\hline Laminaria hyperborea Juvenile & $\mathrm{R}$ & & $2 . \overline{2}$ & & & 1 & 3.2 & \pm & 0.1 & & 3 \\
\hline Laminaria hyeperborea Stipe & $S$ & 4.7 & \pm & 0.4 & & 3 & 5.4 & \pm & 0.3 & & 5 \\
\hline Laminaria hyperborea EPS & $\mathrm{S}$ & 6.1 & \pm & 0.5 & & 3 & 8.1 & \pm & 0.1 & & 3 \\
\hline $\begin{array}{l}\text { Laminaria hyperborea Old } \\
\text { Lamina }\end{array}$ & $\mathrm{S}$ & 4.9 & \pm & 0.7 & & 3 & 3.6 & \pm & 0.4 & & 6 \\
\hline Laminaria hyperborea Young Lamina & $S$ & 2.1 & \pm & 0.6 & & 5 & 1.2 & \pm & 0.1 & & 5 \\
\hline Saccorhiza polyschides & $\mathrm{R}$ & 2.7 & \pm & 0.7 & & 3 & 2.8 & \pm & & & 3 \\
\hline \multicolumn{12}{|l|}{ Ulvophyceae } \\
\hline Ulva rigida & $\mathrm{S}$ & 4.3 & \pm & 0.1 & & 3 & & & & & \\
\hline \multicolumn{12}{|l|}{ OM pool } \\
\hline HOM & $\mathrm{H}$ & 8.9 & \pm & 0.1 & & 3 & 5.3 & \pm & 0.1 & & 3 \\
\hline POM & $\mathrm{W}$ & 4.6 & \pm & 0.6 & & 3 & 5.5 & & 0.3 & & 3 \\
\hline ROM & $\mathrm{R}$ & 7.8 & \pm & 0.2 & & 3 & 6.7 & \pm & 0.6 & & 3 \\
\hline SOM & $\mathrm{R}$ & 6.5 & \pm & 0.1 & & 3 & 6.1 & \pm & 0.1 & & 3 \\
\hline
\end{tabular}

\section{Consumers}

Amphilectus fucorum

Halichondria panicea

Ophlitaspongia papilla

Phorbas plumosum

Sycon ciliatum

Nematoda spp.

Lineus longissimus

Branchiomma bombyx

Eupolymnia nesidensis

Nicolea venustula

Nicolea zostericola

Pista elongata

Harmothoe impar

Leonnates glauca

Odontosyllis ctenostoma

Platynereis dumerilii

Syllis columbretensis

Porifera

$\begin{array}{llllllllllll}\text { SSF } & \mathrm{H} & 5.5 & \pm & 0.3 & 2 & 3 & 6.7 & \pm & 0.2 & 2 & 3 \\ \mathrm{SSF} & \mathrm{R} & & & & & & 6.7 & \pm & 0.2 & 2 & 3 \\ \mathrm{SSF} & \mathrm{S} & 8.2 & \pm & 0.2 & 2.5 & 3 & 7.5 & \pm & 0.2 & 2.3 & 5 \\ \mathrm{SSF} & \mathrm{S} & 7.6 & \pm & 0.3 & 2.3 & 3 & & & & & \\ \text { SSF } & \mathrm{S} & & & & & & 5.4 & \pm & 0.2 & 2 & 3\end{array}$

$$
\begin{array}{llllll}
11.2 & 3.7 & 1 & 11.4 & 3.9 & 1
\end{array}
$$$$
\begin{array}{lll}
13.2 & 4.5 & 1
\end{array}
$$

Annelida

$\begin{array}{cccccccccccc}\text { MSF } & \mathrm{H} & 8.2 & \pm & 0.6 & 2.5 & 3 & 6.4 & \pm & 0.4 & 2 & 3 \\ \mathrm{DF} & \mathrm{S}+\mathrm{H} & 8.7 & \pm & 1.3 & 2.7 & 10 & & & & & \\ \mathrm{DF} & \mathrm{H} & 8.3 & \pm & 0.1 & 2.6 & 5 & 8.4 & \pm & 0.2 & 2.7 & 3 \\ \mathrm{DF} & \mathrm{R} & 7.3 & \pm & 0.4 & 2.2 & 3 & & & & & \\ \text { DF } & \mathrm{R} & & 7.2 & & 2.1 & 1 & & & & & \\ \text { mf-P } & \mathrm{H} & & 12.8 & & 4.4 & 1 & 10.9 & \pm & 0.3 & 3.7 & 5 \\ \text { sf-P } & \mathrm{H} & & & & & & 9.7 & \pm & 0.2 & 3.2 & 3 \\ \text { sf-P } & \mathrm{H} & & & & & & 8.3 & \pm & 0.3 & 2.6 & 5 \\ \text { G } & \mathrm{S}+\mathrm{H} & 9 & \pm & 0.6 & 2.8 & 10 & & & & & \\ \text { sf-P } & \mathrm{S} & & 9.9 & & 3.2 & 1 & & & & & \end{array}$


Syllis variegata

Trypanosyllis zebra

Copepoda spp.

Gnathia dentata

Janira maculosa

Apseudes talpa

Elasmopus rapax

Gammaropsis maculata

Hommarus gammarus

Jassa falcata

Leucothoe spinicarpa

Maera inaequipes

Eualus occultus

Cancer pagurus

Galathea squamifera

Necora puber

Pisidia longicornis

Porcellana platycheles

Mollusca

Acanthochitona crinita

Barleeia unifasciata

Bittium reticulatum

Calliostoma zizyphinum

Gibbula cineraria

Haliotis tuberculata

Ocenebra erinacea

Ocinebrina aciculata

Patella pellucida

Rissoa parva

Tricolia pullus

Trivia arctica

Anomia ephippium

Hiatella arctica

Musculus subpictus

Alcyonidium gelatinosum

Crisia eburnea

Electra pilosa

Echinodermata

Amphipholis squamata

Asterias rubens

Asterina gibbosa

Echinus esculentus

Marthasterias glacialis

Psammechinus milliaris

Chordata

Botryllus schlosseri

Didemnum maculosum

Distomus variolosus

Polyclinum aurantium

Crustacea

Bryozoa
sf-P H

sf-P S

$11 \pm 0.13 .63$

9.6

3.21

mf-P $\mathrm{S}$

$$
7.5
$$

$$
2.2 \quad 1
$$$$
7.1 \pm 0.2 \quad 2.23
$$

DF $\mathrm{H}$

DF $\mathrm{H}$

G H

G H

$\mathrm{P} \quad \mathrm{R}$

MSF $S$

DF R

DF $\mathrm{H}$

mf-P $\quad \mathrm{R}$

mf-P $R$

DF $\quad R$

mf-P $\mathrm{R}$

MSF H

MSF H

sf-P $\quad H$

DF $R$

DF $\mathrm{H}$

sf-P R

G S

G R

sf-P R

sf-P R

G S

DF $\mathrm{H}+\mathrm{R}$

$\begin{array}{lll}11.1 & 3.7 \quad 1\end{array}$

$$
\begin{array}{lll}
7.6 & 2.3 & 1
\end{array}
$$

$\begin{array}{lll}8.8 & 2.8 & 1\end{array}$

$6.4 \pm 0.323$

$14.4 \quad 5 \quad 1$

$5.9 \pm 0.325$

$8.8 \pm 0.52 .8 \quad 3$

$13.7 \pm 0.14 .75$

$12.3 \pm 0.14 .23$

$7.2 \pm 0.92 .13$

$$
\begin{array}{lll}
7.4 & 2.2 \quad 1
\end{array}
$$

$7.6 \pm 0.32 .45$

$9.1 \pm 0.133$

$\begin{array}{lll}11.9 & 4.1 & 1\end{array}$

$\begin{array}{lll}11.4 & 3.9 & 1\end{array}$

$6.8 \pm 0.323$

$7.3 \pm 0.5 \quad 2.23$

$10.8 \pm 0.23 .63$

$$
\begin{array}{lll}
8.6 & 2.7 & 1 \\
8.7 & 2.7 & 1
\end{array}
$$

$11.8 \pm 043$

$9.7 \pm 0.13 .13$

$7.8 \pm 0.42 .45$

$\begin{array}{lll}9.9 & 3.2 & 1\end{array}$

$\begin{array}{lll}8.8 & 2.8 \quad 1\end{array}$

$6.9 \pm 0.325$

G R

sf-P R

SSF $\mathrm{S}$

SSF H

SSF $\mathrm{S}+\mathrm{R}$

$\begin{array}{ll}\text { SSF } & \text { S } \\ \text { SSF } & \text { S } \\ \text { SSF } & \text { S }\end{array}$

$\begin{array}{lll}6.8 & 2 & 1\end{array}$

$7.8 \pm 0.32 .43$

$11.7 \pm 0.23 .93$

$6.4 \pm 0.723$

$6.4 \pm 0.223$

$$
4.7
$$

$5.5 \pm 0.223$

$4.7 \pm 023$

$4.4 \pm 0.223$

$\begin{array}{lllllllll}5.5 & \pm & 0.7 & 2 & 3 & 5.4 & 0.2 & 2 & 3\end{array}$

DF $\quad S$

sf-P R

sf-P $\quad \mathrm{S}+\mathrm{R}$

$7.7 \pm 0.4 \quad 2.3 \quad 3$

$9 \pm 0.1 \quad 2.9 \quad 3$

sf-P $\quad \mathrm{R}$

sf-P R

sf-P R

$$
10.5 \pm 0.2 \quad 3.4 \quad 3
$$$$
9.5 \pm 0.3 \quad 3.13
$$$$
9.4 \pm 0.13 .15
$$

$11.7 \pm 0.243$

$11.1 \pm 0.13 .83$

$$
\begin{array}{lll}
9.5 & 3.1 \quad 1
\end{array}
$$

\begin{tabular}{lccccccccccc}
$\mathrm{SSF}$ & $\mathrm{S}$ & 6 & \pm & 0.8 & 2 & 3 & 5.2 & \pm & 0.3 & 2 & 3 \\
$\mathrm{SSF}$ & $\mathrm{H}$ & 6.1 & \pm & 0.2 & 2 & 3 & 6.4 & \pm & 0.5 & 2 & 3 \\
$\mathrm{SSF}$ & $\mathrm{S}$ & & & & & & 7 & \pm & 0.3 & 2.1 & 5 \\
$\mathrm{SSF}$ & $\mathrm{R}$ & 7.1 & \pm & 0.1 & 2.1 & 3 & 7.2 & \pm & 0.4 & 2.2 & 3 \\
\hline
\end{tabular}


Fig. 1.
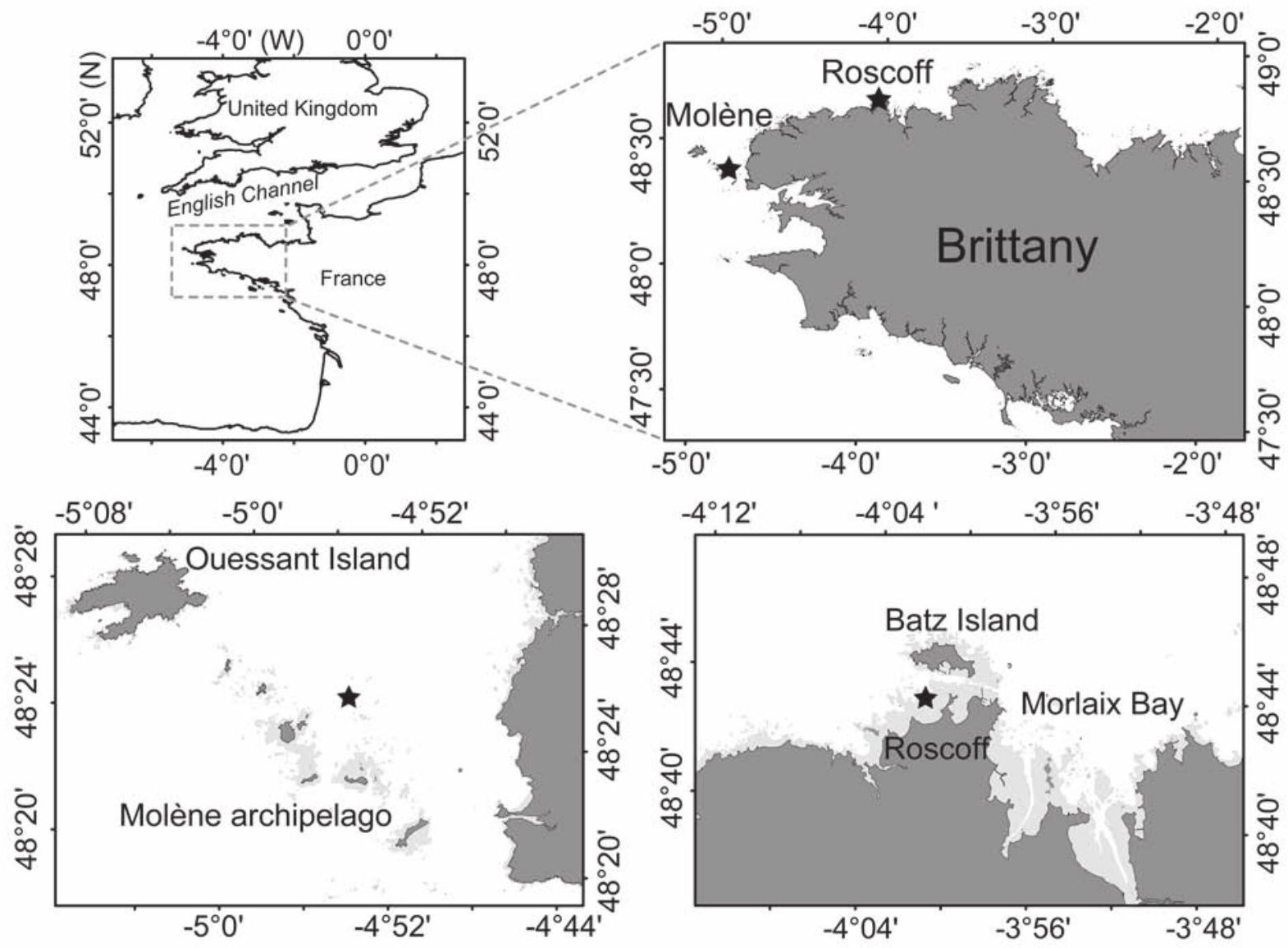
Fig. 2

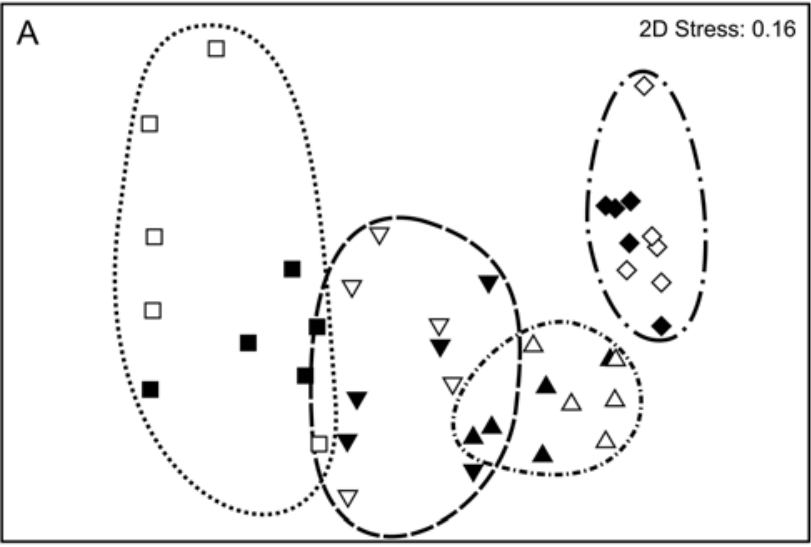

B

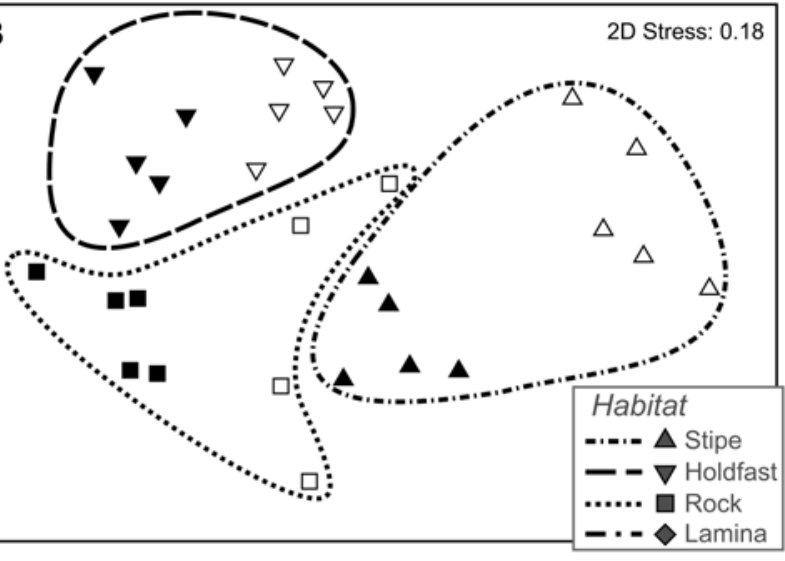


Fig. 4
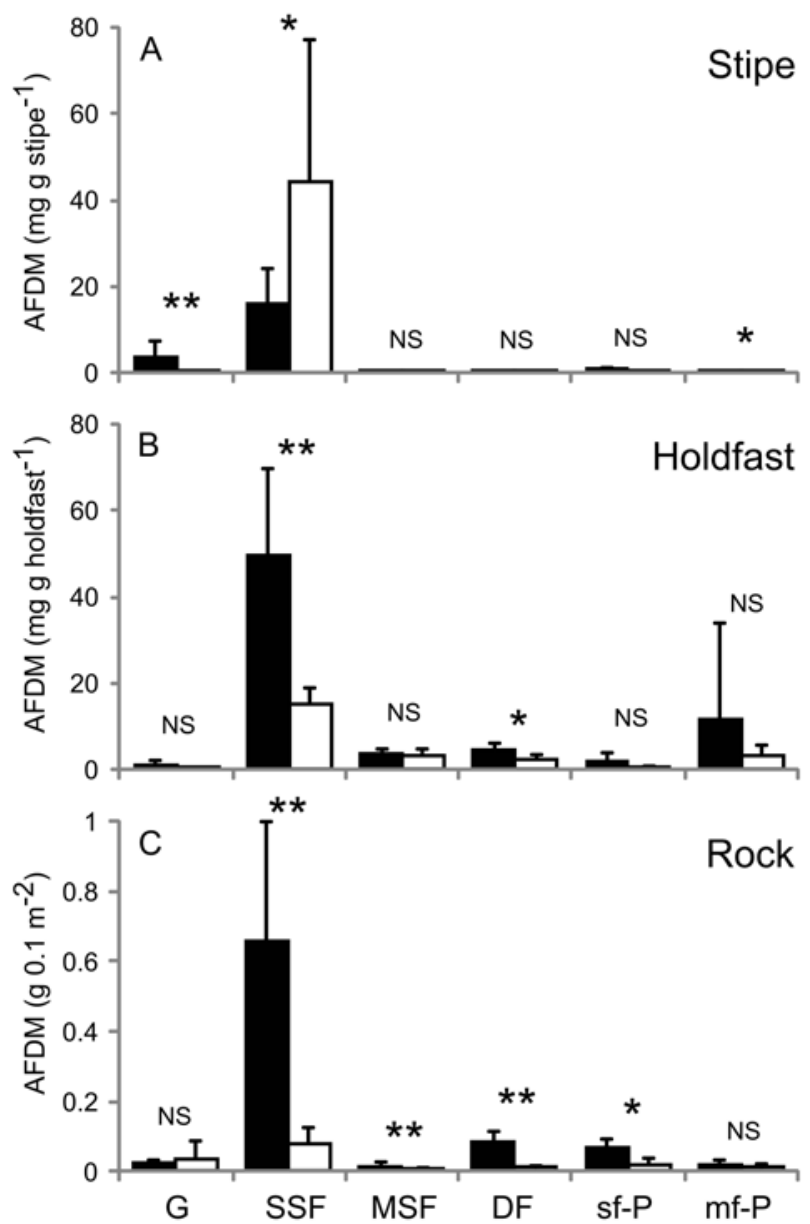
Fig. 5

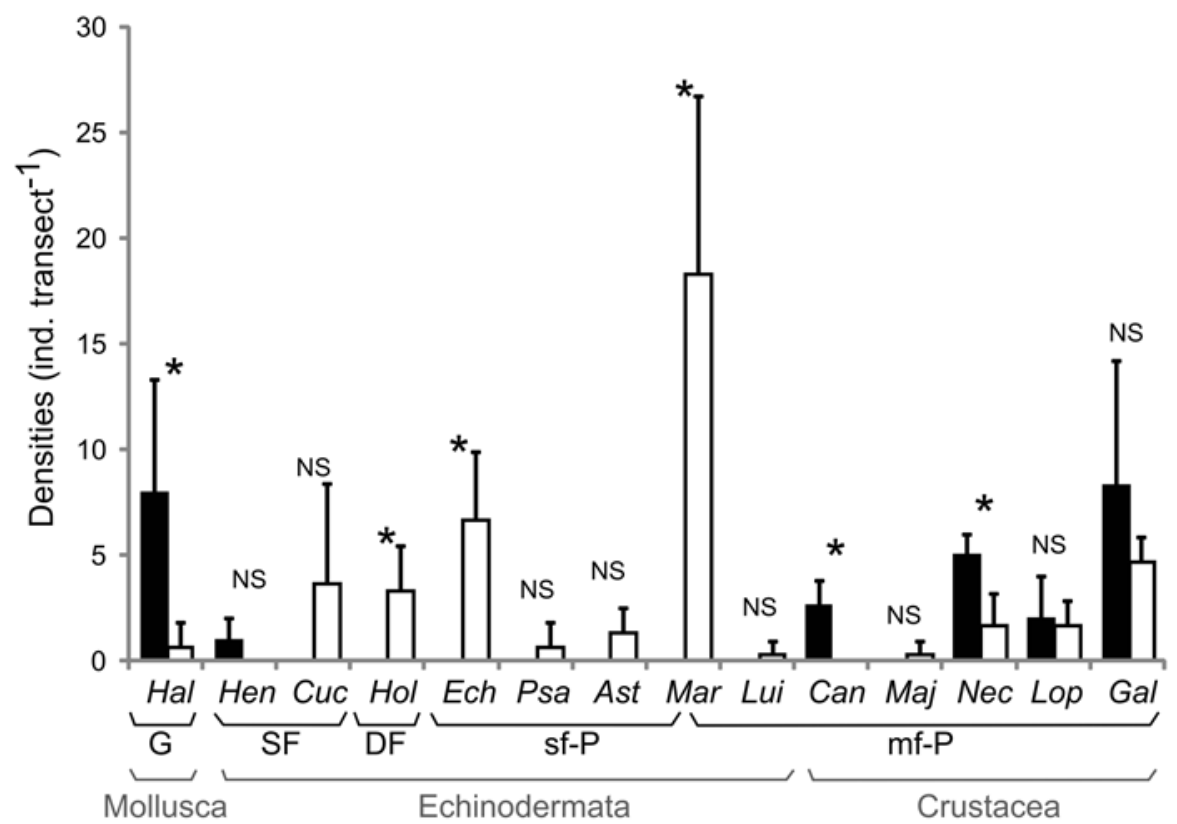


Fig. 6

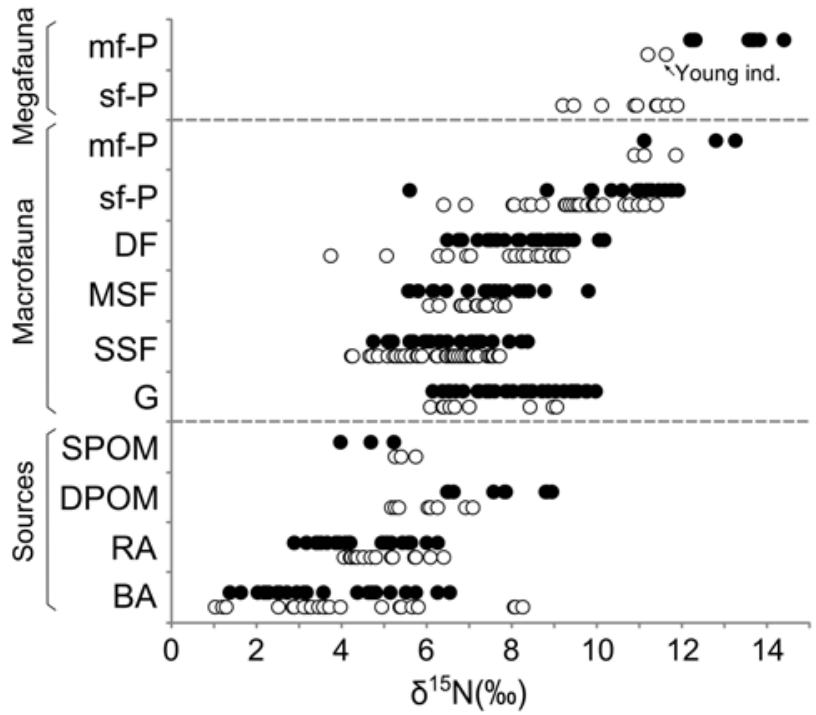




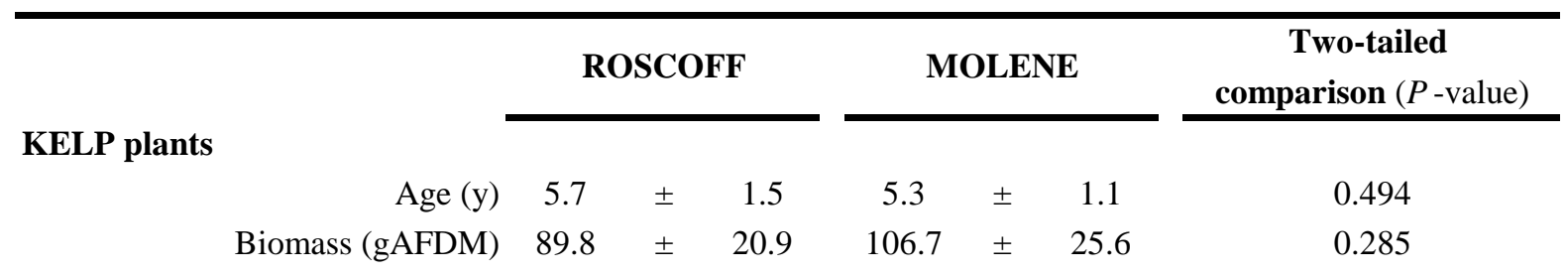

\section{LAMINA}

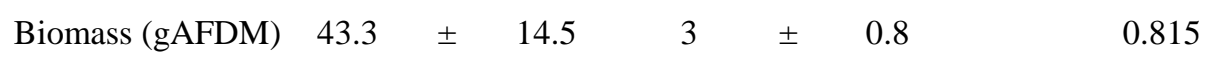

\section{STIPE}

$\begin{array}{rccccccc}\text { Length }(\mathrm{cm}) & 89.0 & \pm & 9.3 & 92.9 & \pm & 21.8 & 0.725 \\ \text { Biomass }(\mathrm{gAFDM}) & 32.0 & \pm & 9.5 & 41.5 & \pm & 15.8 & 0.283 \\ \text { Mean diameter }(\mathrm{mm}) & 22.8 & \pm & 2.4 & 28.2 & \pm & 1.5 & \mathbf{0 . 0 0 3} \\ \text { Total volume }(\mathrm{mL}) & 203.5 & \pm & 35.0 & 264.1 & \pm & 74.1 & 0.137 \\ \text { Surface area }\left(\mathrm{cm}^{2}\right) & 368.7 & \pm & 98.5 & 590.74 & \pm & 193.83 & 0.052\end{array}$

\section{HOLDFAST}

$\begin{array}{rccccccc}\text { Biomass }(\mathrm{gAFDM}) & 14.5 & \pm & 4.8 & 19.6 & \pm & 4.1 & 0.108 \\ \text { Total volume }(\mathrm{mL}) & 511.2 & \pm & 338.2 & 597.0 & \pm & 202.3 & 0.639 \\ \text { rstitial volume }(\mathrm{mL}) & 356.2 & \pm & 267.7 & 390.0 & \pm & 159.8 & 0.815\end{array}$




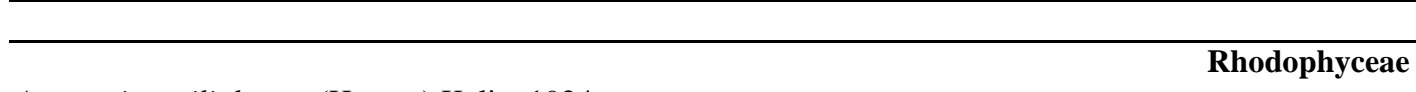

Acrosorium ciliolatum (Harvey) Kylin, 1924

Aglaothamnion bipinnatum (P.L.Crouan \& H.M.Crouan) Feldmann \& G.Feldmann, 1948

Aglaothamnion gallicum (Nägeli) Halos ex Ardré, 1970

Aglaothamnion priceanum Maggs, Guiry \& Rueness, 1991

Aglaothamnion sp. Feldmann-Mazoyer, 1941

Aglaothamnion tenuissimum (Bonnemaison) Feldmann-Mazoyer, 1941

Antithamnionella sp. Lyle, 1922

Apoglossum ruscifolium (Turner) J.Agardh, 1898

Asparagopsis armata Harvey, 1855 (Falkenbergia rufolanosa Stage (Harvey) F.Schmitz, 1897)

Bonnemaisonia asparagoides (Woodward) C.Agardh, 1822

Brongniartella byssoides (Goodenough \& Woodward) F.Schmitz, 1893

Calliblepharis ciliata (Hudson) Kützing, 1843

Callithamnion tetragonum (Withering) S.F.Gray, 1821

Callophyllis laciniata (Hudson) Kützing, 1843

Ceramium pallidum (Nägeli ex Kützing) Maggs \& Hommersand, 1993

Chondria dasyphylla (Woodward) C.Agardh, 1817

Corallina elongata J.Ellis \& Solander, 1786

Corallinale sp. / Peyssoniella sp. Complex

Cryptopleura ramosa (Hudson) L.Newton, 1931

Dasya sp. C.Agardh, 1824

Delesseria sanguinea (Hudson) J.V.Lamouroux, 1813

Dilsea carnosa (Schmidel) Kuntze, 1898

Gracilaria sp. Greville, 1830

Halurus flosculosus (J.Ellis) Maggs \& Hommersand, 1993

Haraldiophyllum bonnemaisonii (Kylin) A.D.Zinova, 1981

Heterosiphonia plumosa (J.Ellis) Batters, 1902

Hypoglossum hypoglossoides (Stackhouse) F.S.Collins \& Hervey, 1917

Kallymenia reniformis (Turner) J.Agardh, 1842

Lomentaria articulata (Hudson) Lyngbye, 1819

Lomentaria clavellosa (Lightfoot ex Turner) Gaillon, 1828

Membranoptera alata (Hudson) Stackhouse, 1809

Palmaria palmata (Linnaeus) Weber \& Mohr, 1805

Phycodrys rubens (Linnaeus) Batters, 1902

Phyllophora crispa (Hudson) P.S.Dixon, 1964

Plocamium cartilagineum (Linnaeus) P.S.Dixon, 1967

Plumaria plumosa (Hudson) Kuntze, 1891

Polyneura bonnemaisonii (C.Agardh) Maggs \& Hommersand, 1993

Polysiphonia brodiaei (Dillwyn) Sprengel, 1827

Polysiphonia elongata (Hudson) Sprengel, 1827

Polysiphonia sp. Greville, 1823

Pterosiphonia parasitica (Hudson) Falkenberg, 1901

Pterothamnion crispum (Ducluzeau) Nägeli, 1862

Ptilothamnion pluma (Dillwyn) Thuret, 1863

Ptilothamnion sphaericum (P.L.Crouan \& H.M.Crouan ex J.Agardh) Maggs \& Hommersand, 1993

$x x x$

$\mathrm{X}$

$\mathrm{XX}$

$\mathrm{XX}$

$\mathrm{xXX}$

$\mathrm{XXX}$

$\mathrm{XX}$

xxx

$x x$

$\mathrm{xXX}$

XX

$\mathrm{xX}$

$x x$

$x x x$

$x x x$

Xx

XX

XX

$\mathrm{XXX}$

$x x x$

$x x$

XX

$\mathrm{xxX}$

$x x$

$x x$

$x x x$

$\mathrm{XXX}$

$X X$

$x x x$

$x x$

$\mathrm{xXX}$

$x$

$x x$

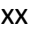

$x x$

$\mathrm{XX}$

Pyllophoraceae sp.

Rhodochorton purpureum (Lightfoot) Rosenvinge, 1900

Rhodophyllis divaricata (Stackhouse) Papenfuss, 1950

Rhodymenia pseudopalmata (J.V.Lamouroux) P.C.Silva, 1952

Sphaerococcus coronopifolius Stackhouse, 1797

Sphondylothamnion multifidum (Hudson) Nägeli, 1862

Chaetopteris plumosa (Lyngbye) Kützing, 1843

Cutleria multifida (Turner) Greville, 1830

Cystoseira sp. C.Agardh, 1820

Dictyota dichotoma (Hudson) J.V.Lamouroux, 1809

Ectocarpus fasciculatus Harvey, 1841

Ectocarpus sp. Lyngbye, 1819 / Hincksia hincksiae (Harvey) P.C.Silva, 1987

Halopteris filicina (Grateloup) Kützing, 1843

Laminaria digitata (Hudson) J.V.Lamouroux, 1813

Laminaria hyperborea (Gunnerus) Foslie, 1884

Phaeophyceae

$x x x$

$x x$

$x x$

$\mathrm{Xx}$

$x x x$

$x$

$\mathrm{XX}$

$x x x$

$x x x$

$\mathrm{XX}$

XXX

$x x x$

$x x x$

$x x$

$x x x$

$x x x$

XXX

$x x$

XX

XXX

$\mathrm{XX}$

$\mathrm{X}$

$\mathrm{X}$

XXX

$x x x$

$x x$

$\mathrm{XX}$ 
Cladophora sp.1 Kützing, 1843

Ulvophyceae

Cladophora sp.2 Kützing, 1844

Ulva sp. (compressa) Linnaeus, 1753

Ulva rigida C.Agardh, 1823

Umbraulva sp. E.H.Bae \& I.K.Lee, 2001

$\mathrm{xx} \quad \mathrm{x}$




\section{Roscoff Molène}

\section{Porifera}

Amphilectus fucorum (Esper, 1794)

Axinella (Schmidt, 1862) sp.

Clathrina (Gray, 1867) sp.

Dysidea fragilis (Montagu, 1818)

Grantia compressa (Fabricius, 1780)

Guancha lacunosa (Johnston, 1842)

Halichondria (Fleming, 1828) sp.

Halichondria (Halichondria) panicea (Pallas, 1766)

Haliclona (Grant, 1836) spp.

Halisarca dujardinii (Johnston, 1842)

Hymeniacidon perlevis (Montagu, 1818)

Leucandra gossei (Bowerbank, 1862)

Leuconia johnstonii (Carter, 1871)

Leuconia nivea (Grant, 1826)

Myxilla (Myxilla) incrustans (Johnston, 1842)

Myxilla (Myxilla) rosacea (Lieberkühn, 1859)

Ophlitaspongia papilla (Bowerbank, 1866)

Phorbas plumosus (Montagu, 1818)

Porifera sp.

Suberitidae sp.

Sycon ciliatum (Fabricius, 1780)

Tethya aurantium (Pallas, 1766)

Tethya citrina (Sarà \& Melone, 1965)

Amphisbetia operculata (Linnaeus, 1758)

Anemonia viridis (Forskål, 1775)

Diphasia attenuata (Hincks, 1866)

Dynamena pumila (Linnaeus, 1758)

Dyphasia (Agassiz, 1862) sp.

Kirchenpaueria pinnata (Linnaeus, 1758)

Lucernariopsis cruxmelitensis (Corbin, 1978)

Orthopyxis integra (MacGillivray, 1842)

Sertularella polyzonias (Linnaeus, 1758)

Urticina felina (Linnaeus, 1761)

Pedicellina nutans (Dalyell, 1848)

Cyanophthalma cordiceps (Friedrich, 1933)

Lineus (Sowerby, 1806) sp. (ruber/sanguineus )

Micrura (Ehrenberg, 1871) sp.

Nemertea sp.

Oerstedia dorsalis (Abildgaard, 1806)

Tubulanus linearis (McIntosh, 1874)
XXX

$x$

$x x$

$x x x$

$x x$

$x x x$

$x x$

$x x x$

$x x x$

XX

$x x x$

$x x$

XXX

$\mathrm{XXX}$

$\mathrm{XXX}$

$\mathrm{XX}$

$x x$

$x x$

$\mathrm{X}$

$\mathrm{XXX}$

$x x x$

$\mathrm{XX}$

$\mathrm{XX}$

$x x x$

$x x$

XXX

$x$

$x$

\section{Cnidaria}

0

$x x$

XX

$\mathrm{x}$

$x X$

$\mathrm{X}$

XXX

$x x-x$

$x$

XX

0

XX

XX

XX

Entoprocta

0

0

Xx $\quad x x$

Nemertea

$\begin{array}{ll}x x & x x x\end{array}$

$x x \quad x x$

$x x \quad x x$

$x x x$

$x x \quad x x$

$x x$

Mollusca

Polyplacophora 
Alvania cancellata (da Costa, 1778)

Gastropoda

Barleeia unifasciata (Montagu, 1803)

$\mathrm{X}$

Bittium reticulatum (da Costa, 1778)

Calliostoma zizyphinum (Linnaeus, 1758)

Cerithiopsis barleei (Jeffreys, 1867)

Cerithiopsis tubercularis (Montagu, 1803)

Chauvetia brunnea (Donovan, 1804)

Crisilla semistriata (Montagu, 1808)

Gibbula cineraria (Linnaeus, 1758)

Gibbula umbilicalis (da Costa, 1778)

Haliotis tuberculata (Linnaeus, 1758)

$X X$

$X X$

$x x x$

$x$

$X X$

$\mathrm{x}$

$x x \quad x$

$x x x \quad x x$

$x X X \quad x X$

$x X X$

$x$

$x$

000

0

Jujubinus (Monterosato, 1884) sp.

Lacuna pallidula (da Costa, 1778)

Lacuna parva (da Costa, 1778)

Lamellaria latens (Müller O.F., 1776)

Manzonia crassa (Kanmacher, 1798)

Marshallora adversa (Montagu, 1803)

Nassarius incrassatus (Strøm, 1768)

XXX

$x \quad x$

$x$

$x x$

$x x$

$\mathrm{x}$

$x X$

$x$

Ocenebra erinaceus (Linnaeus, 1758)

$x$

Ocinebrina aciculata (Lamarck, 1822)

$\mathrm{XX}$

$x x$

Odostomia unidentata (Montagu, 1803)

$x$

Onoba semicostata (Montagu, 1803)

$x X$

$x X$

Patella pellucida (Linnaeus, 1758)

Pleurobranchus membranaceus (Montagu, 1815)

$x x x$

$x$

$x x x$

Pusillina inconspicua (Alder, 1844)

Raphitoma linearis (Montagu, 1803)

$x$

$\mathrm{X}$

Raphitoma purpurea (Montagu, 1803)

Retusa truncatula (Bruguière, 1792)

Rissoa lilacina (Récluz, 1843)

Rissoa membranacea (J. Adams, 1800)

$\mathrm{X}$

$x$

$x$

Rissoa parva (da Costa, 1778)

Tectura virginea (O.F. Müller, 1776)

Tricolia pullus (Linnaeus, 1758)

$\mathrm{XXX}$

$x X$

$x X X$

$x x$

$$
\mathrm{X}
$$

Bivalvia

Aequipecten opercularis (Linnaeus, 1758)

Anomia ephippium (Linnaeus, 1758)

$x x x$

$x$

Rhomboidella prideauxi (Leach, 1815)

$x$

Mimachlamys varia (Linnaeus, 1758)

$x$

Hiatella arctica (Linnaeus, 1767)

$x x$

Kellia suborbicularis (Montagu, 1803)

$x X$

$x X$

Modiolula phaseolina (Philippi, 1844)

$x x$

Musculus discors (Linnaeus, 1767)

Musculus subpictus (Cantraine, 1835)

$x x$

$x X$ 


\section{Sipuncula}

Nephasoma (Nephasoma) minutum (Keferstein, 1862a)

$\mathrm{XX} \quad \mathrm{XX}$

Aetea anguina (Linnaeus, 1758)

Bryozoa

Alcyonidium gelatinosum (Linnaeus, 1761)

Alcyonidium hirsutum (Fleming, 1828)

Amathia lendigera (Linnaeus, 1758)

Bicellariella ciliata (Linnaeus, 1758)

Caberea boryi (Audouin, 1826)

Callopora lineata (Linnaeus, 1767)

Cellepora pumicosa ( Pallas, 1766)

Celleporella hyalina (Linnaeus, 1767)

Celleporina caliciformis (Lamouroux, 1816)

Crisia aculeata (Hassall, 1841)

Crisia denticulata (Lamarck, 1816)

Crisia eburnea (Linnaeus, 1758)

Crisidia cornuta (Linnaeus, 1758)

XX $\quad X X X$

$x X X \quad x X$

$x x \quad x x$

$x x \quad x$

$x x \quad x x$

$x x \quad x$

$x X X \quad x X X$

$x x \quad x x x$

$x x x \quad x x x$

$\mathrm{xxX} \quad \mathrm{XXX}$

$x x$

$x X X \quad x X X$

$x x \quad x x x$

$x X \quad x x x$

Electra pilosa (Linnaeus, 1767)

$x X X$

$x X X \quad x$

Escharoides coccinea (Abildgaard, 1806)

Filicrisia geniculata (Milne Edwards, 1838)

$x x x \quad x x x$

Flustrellidra hispida (O. Fabricius, 1780)

$x x$

$x x$

Haplopoma impressum (Audouin, 1826)

$x x$

$x x x$

XXX

Lichenopora verrucaria (O. Fabricius, 1780)

Membranipora membranacea (Linnaeus, 1767)

Membraniporella nitida (Johnston, 1838)

Microporella ciliata (Pallas, 1766)

Oshurkovia littoralis (Hastings, 1944)

Phaeostachys spinifera (Johnston, 1847)

Plagioecia sarniensis (Norman, 1864)

Plesiothoa gigerium (Ryland \& Gordon, 1977)

Ramphonotus minax (Busk, 1860)

Schizomavella auriculata (Hassall, 1842)

Schizomavella hastata (Hincks, 1862)

Schizomavella linearis (Hassall, 1841)

Scruparia chelata (Linnaeus, 1758)

Scrupocellaria reptans (Linnaeus, 1758)

$x x$

$x \quad x$

$x x$

$x x x \quad x x x$

$x x x \quad x$

$x$

$x x x \quad x x$

$\mathrm{X}$

Scrupocellaria scabra (van Beneden, 1848)

Scrupocellaria scruposa (Linnaeus, 1758)

Tubulipora plumosa (Thompson in Harmer, 1898)

Turbicellepora magnicostata (Barroso, 1919)

Vesicularia spinosa (Linnaeus, 1758)

Annelida

Ctenodrilidae

Ctenodrilidae sp. (Kennell, 1882)

Eunicidae

Eunicidae (Berthold, 1827) indet.

$\mathrm{XX}$ 
Nereidae

Leonnates glauca (Claparède, 1870)

Nereis pelagica (Linnaeus, 1758)

Platynereis dumerilii (Audouin \& Milne Edwards, 1834)

$\mathrm{xX} \quad \mathrm{XxX}$

$x X X$

Syllidae

Amblyosyllis formosa (Claparède, 1863)

Autolytinae (Langherans, 1879) indet.

Eurysyllis tuberculata (Ehlers, 1864)

Eusyllis assimilis (Marenzeller, 1875)

$x x x$

$X X X$

Eusyllis blomstrandi (Malmgren, 1867)

Exogone (Exogone) naidina (Örsted, 1845)

Exogone (Örsted, 1845) sp.

Haplosyllis spongicola (Grube, 1855)

Myrianida prolifera (O.F. Müller, 1788)

Odontosyllis ctenostoma (Claparède, 1868)

Pionosyllis lamelligera (Saint Joseph, 1887)

Sphaerosyllis hystrix (Claparède, 1863)

Syllis (Lamarck, 1818) sp.

Syllis armillaris (O.F. Müller, 1776)

Syllis columbretensis (Campoy, 1982)

Syllis gracilis (Grube, 1840)

Syllis hyalina (Grube, 1863)

Syllis variegata (Grube, 1860)

Trypanosyllis (Trypanosyllis) coeliaca (Claparède, 1868)

Trypanosyllis zebra (Grube, 1840)

$\begin{array}{cc}x & x x \\ & x x \\ & x x \\ & x x \\ x x & x x x \\ & x x \\ x x x & x x \\ & x \\ x x x & x x \\ x & x x x \\ & x \\ & x \\ x x & x x \\ x x x & x x x \\ x & x x x \\ & x x x \\ x x x & x \\ x & x x x \\ x x & x \\ & x x\end{array}$

Eumida sanguinea (Örsted, 1843)

Phyllodocidae

Nereiphylla rubiginosa (Saint-Joseph, 1888)

Phyllodoce ( Lamarck, 1818 ) sp.

$x X$

$x x$

$\mathrm{X}$

Polynoidae

Harmothoe extenuata (Grube, 1840)

Harmothoe impar (Johnston, 1839)

Harmothoe spinifera (Ehlers, 1864)

$\mathrm{XX}$

$\mathrm{XXX}$

$\mathrm{XX}$

$\mathrm{XX}$

$\mathrm{XX}$

$\mathrm{XX}$

Lepidonotus clava (Montagu, 1808)

$x X$

$\mathrm{XX}$

Pholoe inornata (Johnston, 1839)

$x x$

$x$

Orbiniidae

Proscoloplos cygnochaetus (Day, 1954)

Nichomache (Malmgren, 1865) spp.

$\mathrm{XX}$

Maldanidae

Arenicolidae

Arenicolides ecaudata (Johnston, 1835)

Spionidae

$\begin{array}{cc}x x & x x \\ x x & x x \\ & x \\ x x & x x\end{array}$

Aonides oxycephala (Sars, 1862)

Dipolydora (Verrill, 1881) sp.

Pseudopolydora (Czerniavsky, 1881) sp.

Scolelepis tridentata (Southern, 1914)

$\mathrm{XX}$

$\mathrm{XX}$ 
Sabellidae

Amphiglena mediterranea (Leydig, 1851)

Branchiomma bombyx (Dalyell, 1853)

Branchiomma lucullanum (Delle Chiaje, 1828)

Fabricia sabella (Ehrenberg, 1836)

Jasmineira elegans (Saint-Joseph, 1894)

Oridia armandi (Claparède, 1864)

Parasabella langerhansi (Knight-Jones, 1983)

Pseudopotamilla reniformis (Bruguière, 1789)

Sabella discifera (Grube, 1874)

Sabellaria spinulosa (Leuckart, 1849)

Sabellariidae

Serpudidae

Protula tubularia (Montagu, 1803)

Salmacina (Claparède, 1870) sp.

Spirorbis corrugatus (Montagu, 1803)

Spirorbis (Daudin, 1800) sp.

Spirobranchus triqueter (Linnaeus, 1758)

$\begin{array}{cc}x x x & x x x \\ x x x & x x x \\ x & \\ x x & x x \\ x x & x x x \\ & x \\ x x & x x \\ x & \\ x & x\end{array}$

$\mathrm{XX}$

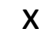

$\mathrm{XX}$

$\mathrm{X}$

$x$

$x x x$

$x x x$

$\mathrm{XX}$

Amphitrite johnstoni (Malmgren, 1865)

Eupolymnia nebulosa (Montagu, 1818)

$x$

$\mathrm{X}$

Eupolymnia nesidensis (Delle Chiaje, 1828)

Nicolea venustula (Montagu, 1818)

Nicolea zostericola (Örsted, 1844)

Pista elongata (Moore, 1909)

Polycirrus medusa (Grube, 1850)

Trichobranchus glacialis (Malmgren, 1866)

Chaetognatha

Spadella (Langerhans, 1880) sp.

Platyhelminthes

Cycloporus papillosus (Sars in Jensen, 1878) Lang, 1884

$x$

$X X$

$\mathrm{XXX}$

$x x x$

$x x x$

$x x x$

$x x$

$x x x$

$x x$

$x x$

$x x x$

Stylochoplana maculata (Quatrefage, 1845)

Nematoda

Nematoda spp.

$x x x$

$\mathrm{XXX}$

Achelia echinata (Hodge, 1864)

Pycnogonida

Achelia hispida (Hodge, 1864)

Ammothella longipes (Hodge, 1864)

Anoplodactylus angulatus (Dohrn, 1881)

Callipallene brevirostris (Johnston, 1837)

Endeis spinosa (Montagu, 1808)

Nymphon gracile (Leach, 1814)

Nymphon brevirostre (Hodge, 1863)

$x x x \quad x x x$

$\mathrm{XX}$

$\mathrm{XXX}$

$X$

$\mathrm{XX}$

$x$

$\mathrm{X}$

$x$

$\mathrm{X}$

$\mathrm{X}$

XX

Crustacea

Cirripedia

Verruca stroemia (O.F. Müller, 1776)

$x X X$

$\mathrm{XXX}$

Isopoda

Astacilla danmoniensis (Stebbing, 1874)

$\mathrm{XX}$ 
Calathura norvegica (Sars, 1872)

Dynamene bidentata (Adams, 1800)

$x$

$\mathrm{X}$

$x$

$\mathrm{X}$

Gnathia dentata (G. O. Sars, 1872)

Gnathia maxillaris (Montagu, 1804)

Janira maculosa (Leach, 1814)

Stenosoma lancifer (Miers, 1881)

Isopoda $\mathrm{sp}$.

Nebalia bipes (Fabricius, 1780)

Praunus inermis (Rathke, 1843)

Tanaidacea

Apseudes talpa (Montagu, 1808)

Apseudopsis latreillii (Milne-Edwards, 1828)

Aora spinicornis (Afonso, 1976)

Ampithoe gammaroides (Bate, 1856)

Ampithoe ramondi (Audouin, 1826)

Ampithoe rubricata (Montagu, 1818)

Apherusa bispinosa (Bate, 1857)

Apherusa cirrus (Bate, 1862)

Apherusa jurinei (Milne-Edwards, 1830)

Caprella acanthifera (Leach, 1814)

Caprella fretensis (Stebbing, 1878)

Crassicorophium bonellii (Milne Edwards, 1830)

Dexamine spinosa (Montagu, 1813)

Dexamine thea (Boeck, 1861)

Elasmopus (Costa, 1853)

Gammaropsis maculata (Johnston, 1828)

Iphimedia obesa (Rathke, 1843)

Jassa falcata (Montagu, 1808)

Lembos websteri (Bate, 1857 )

Leucothoe spinicarpa (Abildgaard, 1789)

Lysianassa ceratina (Walker, 1889)

Maera grossimana (Montagu, 1808)

Maera inaequipes (Costa, 1857)

Melita hergensis (Reid, 1939)

Microprotopus (Norman, 1867 sp.

Nannonyx spinimanus (Walker, 1895)

Orchomene humilis (Costa, 1853)

Phtisica marina (Slabber, 1769)

Sunamphitoe pelagica (Milne-Edwards, 1830)

Triphosella (Bonnier, 1893) sp.

Tritaeta gibbosa (Bate, 1862)

Decapoda

Anapagurus hyndmanni (Bell, 1846)

$x x x$

$\mathrm{XX}$

$x x$

$x x$

$\mathrm{XX}$

$x x x$

$x x$

$x x$

$\mathrm{XX}$

$x x$

$x x$

$x$

$x$

$x$

$x X X$

$x$

$\mathrm{XX}$

$\mathrm{XX}$

$\mathrm{X}$

$x X$

$\mathrm{X}$

$x$

$x X$

$x x$

$x$

$x$

$X X$

$x X$

oo

$x x$

$x$

$x x$

$\mathrm{x}$ $x$

$x X$

$x$

$x x$

$x$

Cancer pagurus (Linnaeus, 1758 ) 
Eualus occultus (Lebour, 1936)

Eualus pusiolus (Krøyer, 1841)

Eurynome spinosa (Hailstone, 1835)

Galathea squamifera (Leach, 1814 )

00

Galathea strigosa (Linnaeus, 1761)

0

Homarus gammarus (Linnaeus, 1758)

Lophozozymus incisus (H. Milne Edwards, 1834)

o

Maja squinado (Herbst, 1788)

0

Necora puber (Linnaeus, 1767)

Pagurus bernhardus (Linnaeus, 1758)

Philocheras fasciatus (Risso, 1816)

Pilumnus hirtellus (Linnaeus, 1761)

Pisidia longicornis (Linnaeus, 1767)

Porcellana platycheles (Pennant, 1777)

Xantho pilipes ( A. Milne-Edwards, 1867)

\section{Echinodermata}

Amphipholis squamata (Delle Chiaje, 1828)

$x x x$

$\mathrm{XXX}$

Antedon bifida (Pennant, 1777)

Aslia lefevrii (Barrois, 1882)

Asterias rubens (Linnaeus, 1758)

$x x x$

$x \quad x x$

Asterina gibbosa (Pennant, 1777)

0

$\mathrm{xX}$

$\mathrm{XXX}$

$x x$

Cucumaria frondosa (Gunnerus, 1767)

0

००

Echinus esculentus (Linnaeus, 1758)

o०

Henricia sanguinolenta (O.F. Müller, 1776)

0

Holothuria (Panningothuria) forskali (Delle Chiaje, 1823)

Luidia ciliaris (Philippi, 1837)

Marthasterias glacialis (Linnaeus, 1758)

0

Ocnus lacteus (Forbes \& Goodsir, 1839)

Ophiothrix fragilis (Abildgaard, in O.F. Müller, 1789)

Pawsonia saxicola (Brady \& Robertson, 1871)

Psammechinus miliaris (P.L.S. Müller, 1771)

Chordata

Aplidium pallidum (Verrill, 1871)

$\mathrm{XX} \quad \mathrm{XX}$

Aplidium punctum (Giard, 1873)

$x x \quad x x$

Aplidium glabrum (Verrill, 1871)

$x \quad x x x$

Aplidium (Savigny, 1816) spp.

$x x x$

$x X X$

Ascidia mentula (Müller, 1776)

$x x$

$\mathrm{XX}$

Botryllus schlosseri (Pallas, 1766)

$x X X$

$x x x \quad x x x$

Clavelinidae [Archidistoma aggregatum (Garstang, 1891)]

$x X$

Dendrodoa grossularia (Van Beneden, 1846)

$x X x$

Didemnum maculosum (Milne-Edwards, 1841)

$X X X$

०००

Distomus variolosus (Gaertner, 1774)

Lissoclinum perforatum (Giard, 1872)

$x x x \quad x x x$

Molgula crinita (Sluiter, 1904)

Morchellium argus (Milne-Edwards, 1841)

Polycarpa (Heller, 1877) sp.

Polyclinum aurantium (Milne-Edwards, 1841)

$x x$

$x x$

$x x x \quad x x x$

$x \quad x x x$

$X X X$

$x x x$

$x x x$

$x X$ 
Pyura (Molina, 1782) sp. 